Portland State University

PDXScholar

7-12-2018

\title{
The Limitations of DNA Interstrand Cross-link Repair in Escherichia coli
}

Jessica Michelle Cole

Portland State University

Follow this and additional works at: https://pdxscholar.library.pdx.edu/open_access_etds

Part of the Biology Commons

Let us know how access to this document benefits you.

\section{Recommended Citation}

Cole, Jessica Michelle, "The Limitations of DNA Interstrand Cross-link Repair in Escherichia coli" (2018). Dissertations and Theses. Paper 4489.

https://doi.org/10.15760/etd.6373

This Thesis is brought to you for free and open access. It has been accepted for inclusion in Dissertations and Theses by an authorized administrator of PDXScholar. Please contact us if we can make this document more accessible: pdxscholar@pdx.edu. 
The Limitations of DNA Interstrand Cross-link Repair in Escherichia coli

by

Jessica Michelle Cole

A thesis submitted in partial fulfillment of the requirements for the degree of

Master of Science

in

Biology

Thesis Committee:

Justin Courcelle, Chair

Jeffrey Singer

Rahul Raghavan

Portland State University

2018 


\begin{abstract}
DNA interstrand cross-links are a form of genomic damage that cause a block to replication and transcription of DNA in cells and cause lethality if unrepaired. Chemical agents that induce cross-links are particularly effective at inactivating rapidly dividing cells and, because of this, have been used to treat hyperproliferative skin disorders such as psoriasis as well as a variety of cancers. However, evidence for the removal of crosslinks from DNA as well as resistance to cross-link-based chemotherapy suggests the existence of a cellular repair mechanism. Characterizing the pathways involved in DNA interstrand cross-link repair has been challenging due to the inherent structure of the damage as it precludes the use of an undamaged, complementary strand of DNA as a template for repair.
\end{abstract}

A number of models of cross-link repair have been proposed based on the identification of hypersensitive repair mutants as well as biochemical evidence that specific repair enzymes are capable of incising cross-linked structures from DNA. Together, these models have suggested the involvement of multiple repair pathwayssuch as nucleotide exicision repair, translesion synthesis, recombination of double-strand breaks, and base excision repair-operating in sequential steps to correct the damage. Most of the studies from which these models arose are complicated by the fact that crosslinking agents induce multiple forms of damage or they lack in vivo confirmation of how the repair phenomenon occurs in organisms.

In this study, I use Escherichia coli as a model organism to examine the involvement of the aforementioned pathways in DNA interstrand cross-link repair in vivo. This 
organism was useful in early cross-link studies and, with its highly conserved repair processes, maintains the potential for delineating how cross-links are removed in higher organisms. In Chapter I, I introduce background information on different cross-linking agents, the complications of studying cross-link repair, and the candidate repair pathways that have been implicated to date.

In Chapter II I demonstrate that there is a limited involvement of the nucleotide excision repair helicase, translesion polymerases, and double-strand break repair enzymes through survival analysis of cells defective in these proteins. For this analysis, I use 8methoxypsoralen plus UVA as a cross-linking agent and angelicin plus UVA as a monofunctional comparator. The observation that $u v r D$ mutants - defective in helicase II of nucleotide excision repair-were nearly as resistant to 8-methoxypsoralen-induced damage as wild type cells led me to examine the incision rate of cross-links from endogenous plasmid DNA. Surprisingly, cross-links were not efficiently removed from DNA in $u v r D$ mutants relative to wild type cells. These seemingly contradictory results were rectified when I quantified cross-link formation in cell cultures and revealed that as few as one cross-link per chromosome can inactive wild type cells, a lethal quantity that is lower than what has been previously reported. Taken together, these observations suggest that although cross-links are incised in wild type cells, repair is still not a highly productive event in E. coli.

In Chapter III I examine the involvement of the base excision repair pathway in crosslink repair and demonstrate that Nth and Fpg Glycosylases, Xth and Nfo APEndonucleases sensitize Escherichia coli to psoralen-induced DNA damage. This is shown by comparative survival analysis in angelicin plus UVA and 8-methoxypsoralen 
plus UVA treatment whereby $n t h-, f p g-$, and $x t h$-mutants are each more resistant than wild type cells to either treatment. This suggests that when these gene products are present they impact the production or removal of monoadducts. $n f o$-mutants were different in that the cells were only hyperresistant to 8-methoxypsoralen monoadducts and cross-links, either implying that the Nfo enzyme interacts specifically with psoralen monoadducts rather than angelicin monoadducts or that the enzyme impedes cross-link removal.

Finally, in Chapter IV a summary of the results is provided as well as future directions that may be explored following this study. 


\section{Acknowledgements}

Starting this adventure would not be possible without my immensely supportive and encouraging family, friends, and mentors. Mom \& Dad: thank you for taking that leap of faith and helping me move 3,034.3 miles away from home, despite knowing I was the youngest and least self-sufficient of your children. Laura \& Jesse: thank you for exploring the PNW with me and always being open for meaningful and constructive conversation. Danny \& Jen: thank you for having a big, beautiful, crazy family that I look forward to climbing trees with every time I come home. JPACKK: thank each of you for being so different and inspiring and the best group of lifelong friends a gal could ever hope for. Dr. D’Amato \& Dr. Cook: thank you for teaching me the importance (and fun!) of religion, philosophy, dreams, and logic. Dr. Pi \& Dr. Walsh: thank you for taking in a lost little R \& P major, exposing me to how rad biology (especially the small stuff) can be, and letting me play scientist in your labs.

Enduring this adventure would not be possible without my lab mates and my boyfriend. Brian: thank you letting me bounce my project ideas/concerns off of you and encouraging me to keep moving forward. Nick: thank you for sharing the struggle of science with me, always making me laugh, and going drink for drink with me when a hard day's work called for it. Jeffrey Dillon: thank you for driving me to lab on the weekends, listening to me whine about challenging days at PSU and missing my family, and loving me unconditionally.

Completing this adventure would not be possible without my incredibly helpful PI, Justin and lab manager, Char: Thank you for teaching me every single assay necessary to 
complete this project, understanding my need to blow off smoke at the gym, and taking me in for Thanksgiving dinners when I was without family in Portland. Thank you for opening your doors to a very green science student, discussing all the old cross-link literature with me, being patient and helping me understand my results over and over and over again, and for critically evaluating interpretations of my data. Thank you for breaking my terrible habit of careless and optimistic procrastination and encouraging me to try to figure stuff out by myself before asking for help. Finally, thank you for always having your door open. 
Table of Contents

\begin{tabular}{lc} 
Abstract & Page \\
\hline Acknowledgements & i \\
\hline List of Tables & iv \\
\hline & \\
List of Figures & vii \\
\hline & \\
Chapter I: Introduction & viii \\
\hline \multicolumn{1}{l}{ References } & 1 \\
\hline $\begin{array}{l}\text { Chapter II: Limited capacity or involvement of excision } \\
\text { repair, double-strand breaks, or translesion synthesis for } \\
\text { psoralen cross-link repair in Escherichia coli }\end{array}$ & 12 \\
\hline Abstract & \\
Introduction & \\
Methods & 17 \\
Results & 17 \\
Discussion & 22 \\
References & 25 \\
\end{tabular}

Chapter III: Nth and Fpg Glycosylases, Xth and Nfo AP endonuclease sensitize Escherichia coli to psoraleninduced DNA damage

$\begin{array}{ll}\text { Abstract } & 47 \\ \text { Introduction } & 48 \\ \text { Methods } & 52 \\ \text { Results } & 55 \\ \text { Discussion } & 65 \\ \text { References } & 67\end{array}$

Chapter IV: Conclusion 


\section{List of Tables}

4.1 Summary of in vivo results of $E$. coli mutants from candidate DNA interstrand cross-link repair pathways relative to wild type cells. 


\section{List of Figures}

1.1 DNA interstrand cross-linking agents covalently bound to their preferred DNA bases.

1.2 Angelicin and 8-methoxypsoralen are furocoumarin isomers that intercalate in DNA and preferentially bind to thymine bases in photocycloaddition reactions.

1.3 Prominent models for repair of DNA interstrand cross-links.

2.1 UvrD contributes to survival in the presence of monoadducts but not DNA interstrand cross-links.

2.2 $u v r D$-mutants have diminished capacity for incising DNA interstrand cross-links.

2.3 The transleison DNA polymerases do not contribute to survival in the presence of 8-methoxypsoralen-induced DNA interstrand cross-links.

2.4 RecN, which is required for resistance to double-strand breaks, does not contribute to survival in the presence of DNA interstrand crosslinks.

2.5 One cross-link is sufficient to inactivate our parental strain of E. coli.

3.1 Glycosylases Nei and Fpg and endonucleases Nfi and Nth are not required for 8-methoxysproalen-induced interstrand cross-link survival in E. coli.

3.2 Inactivation of Endonuclease IV confers resistance to 8methoxypsoralen-induced damage.

3.3 Inactivation of glycosylases or AP endonuclease activity does not alter incision rate of 8-methoxypsoralen cross-links from E. coli cells containing plasmid pBR322.

3.4 Cross-link induction in base excision repair mutants is similar to induction in wild type cells. 
Chapter I: Introduction

DNA interstrand cross-links form when chemicals covalently bind complementary strands of DNA. This type of damage obstructs necessary cellular processes such as replication and transcription and is lethal if left unrepaired. Knowledge of cross-linking agents came out of studies that examined the effects of mustard gas and nitrogen mustard employed during the World Wars $(1,2)$. It was observed that these compounds were particularly detrimental to actively dividing cells, such as those found in tumors of mice (3). This finding led to the use of nitrogen mustard as a chemotherapeutic in humans years before the actual mechanism of action was determined to be crosslinking of DNA (3-5). Interestingly, secondary malignancies can arise from the use of cross-linking agents in chemotherapy $(6,7)$. For most, this risk following treatment does not outweigh the benefit. However, for a small population cross-linking agents cannot be repaired and therefore treatment itself can be lethal.

The population that this risk applies to is those afflicted with Fanconi anemia, a rare genetic disorder characterized by bone marrow failure, high susceptibility to acute myeloid leukemia, and diminished capacity for cross-link repair $(8,9)$. One method of diagnosing this disorder involves a chromosome breakage test in which a blood sample is treated with a cross-linking agent and then 72 hours later chromosomes at metaphase are examined $(10,11)$. A positive result is indicated by major chromosomal aberrations, which are consequences of cells that lack the gene products necessary to repair crosslinks (12). 
To date, 21 genes have been associated with the Fanconi anemia pathway (13), yet a complete understanding of how these gene products operate in healthy cells is still being delineated. The proteins identified in this pathway have been characterized by their involvement with the monoubiquitination of a heterodimer complex formed by proteins FANCD2 and FANCI. As such, there are proteins that comprise a core ubiquitin ligase complex responsible for monoubiquitination of $\mathrm{FANCI} / \mathrm{D} 2$ and proteins that are recruited by this unbiquitinated heterodimer and act downstream to unhook cross-links from DNA and restore the damaged DNA site $(13,14)$. The majority of those diagnosed with Fanconi anemia have mutations in the core ubiquitin ligase complex (15), however, genes associated with this pathway are still being identified (16) and the overall repair mechanism of cross-links in humans is only partially understood.

\section{DNA interstrand cross-linking agents}

While there is considerable evidence for the removal of cross-links from DNA in cells, how this form of damage is precisely repaired has remained challenging to characterize. One problem with identifying a repair mechanism is that chemical agents that form cross-links each have different binding (Figure 1.1) and structural effects on DNA. For example, nitrogen mustard binds to guanine bases in 5'-GNC sequences and severely distorts the beta structure of the DNA helix (17-20). Cisplatin preferentially binds guanines in 5'-GC substrates and induces a major bend and minor unwinding in the helical DNA structure. By comparison, mitomycin $\mathrm{C}$ binds to guanines in 5'-CG sequences but does not significantly distort the helix (21-23). Psoralen - the crosslinking agent that is the focus of this study-binds to thymines at 5'-TA sites and only 
modestly distorts DNA upon intercalation and binding $(24,25)$. If cellular recognition of damage is a prerequisite to repair then it may be the case that distinct repair pathways operate on cross-links to remove the various structures formed by different cross-linking agents. Indeed, in vitro studies have reported the involvement of different repair proteins and pathways for different agents (26) (27).

A<smiles>CN(CCn1cnc2nc(N)[nH]c(=O)c21)CCn1cnc2nc(N)[nH]c(=O)c21</smiles>

B<smiles>CCCN(P)[PH](N)(N)n1cnc2nc(N)[nH]c(=O)c21</smiles>
Nitrogen mustard Cisplatin

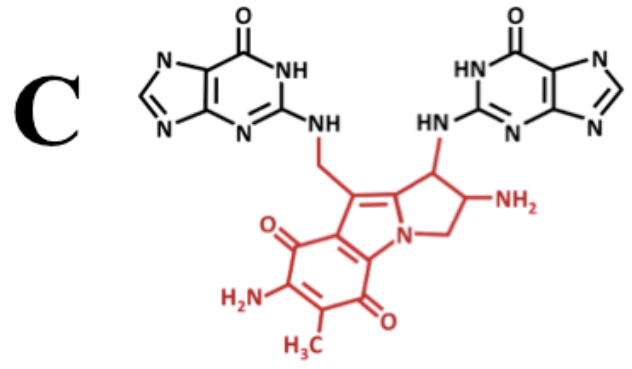
Mitomycin C

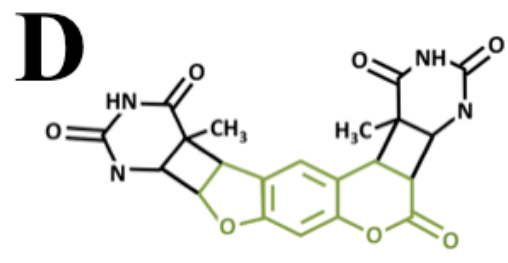

Psoralen

Figure 1.1. DNA interstrand cross-linking agents covalently bound to their preferred DNA bases. A) Nitrogen mustard (yellow) binds to guanine bases in 5'-GNC sequences. B) Cisplatin (blue) binds to guanine bases in 5'-GC sequences. C) Mitomycin (red) C binds to guanine bases in 5'-CG sequences. D) Psoralen (green) binds to thymine bases in 5'-TA sequences.

Another challenge to characterizing the mechanism by which cross-links are repaired is that all cross-linking agents induce multiple forms of damage, not just crosslinks (28). This is a result of cross-linking being a multi-step reaction: the chemical agent intercalates into DNA, covalently binds to a base, and then binds to a base on the 
opposite strand of DNA. Therefore, monoadducts are produced as precursors to crosslinks but can persist as single-stranded damage when sequence context or structural properties preclude the second binding reaction $(29,30)$. Since cells treated with crosslinking agents present a variety of monoadducts, cross-links, and potentially other forms of DNA damage, it is challenging to design experiments where the defect or phenotype can be specifically attributed to the presence or repair of the cross-link. One approach previously used to address this challenge has been to create site-specific cross-links in plasmids and study repair with purified repair proteins or extracts in vitro (31). While this method has provided insight in identifying gene products that are capable of binding to or incising cross-links, it largely remains unknown if these gene products operate on crosslinks similarly in vivo or contribute to the repair process of a living organism.

Since there are no agents that exclusively produce cross-links, a second approach to identifying cross-link-specific effects has been to compare monofunctional agents to related cross-linking agents (32-35). Psoralen has a variety of isomers that have been shown to vary in photo-reactivity with DNA. For example, Angelicin is a psoralen derivative that, due to its angular structure, only produces monoadducts with native DNA $(36,37)$. This isomer binds to the 5,6 -double bond of thymine bases with the 3,4-double bond of its pyrone ring by way of UVA photoreaction (38) (Figure 1.2A). 8methoxypsoralen is another isomer of psoralen that is often used as the cross-linking agent alongside angelicin, since it produces a higher ratio of cross-links to monoadducts than that of psoralen (39). Like psoralen, the linear structure of this molecule allows for binding at the 4',5'- and 3,4- positions of its furan and pyrone rings, respectively, to the 5,6-double bonds of adjacent thymine bases $(40,41)$. There are four major products that 
result from 8-methoxypsoralen plus UVA light and native DNA: two diasterometric furan-side monoadducts, one pyrone-side monoadduct, and one interstrand cross-link where the furan-side monoaddition necessarily precedes the pyrone-side addition $(29,42)$ (Figure 1.2B-E).
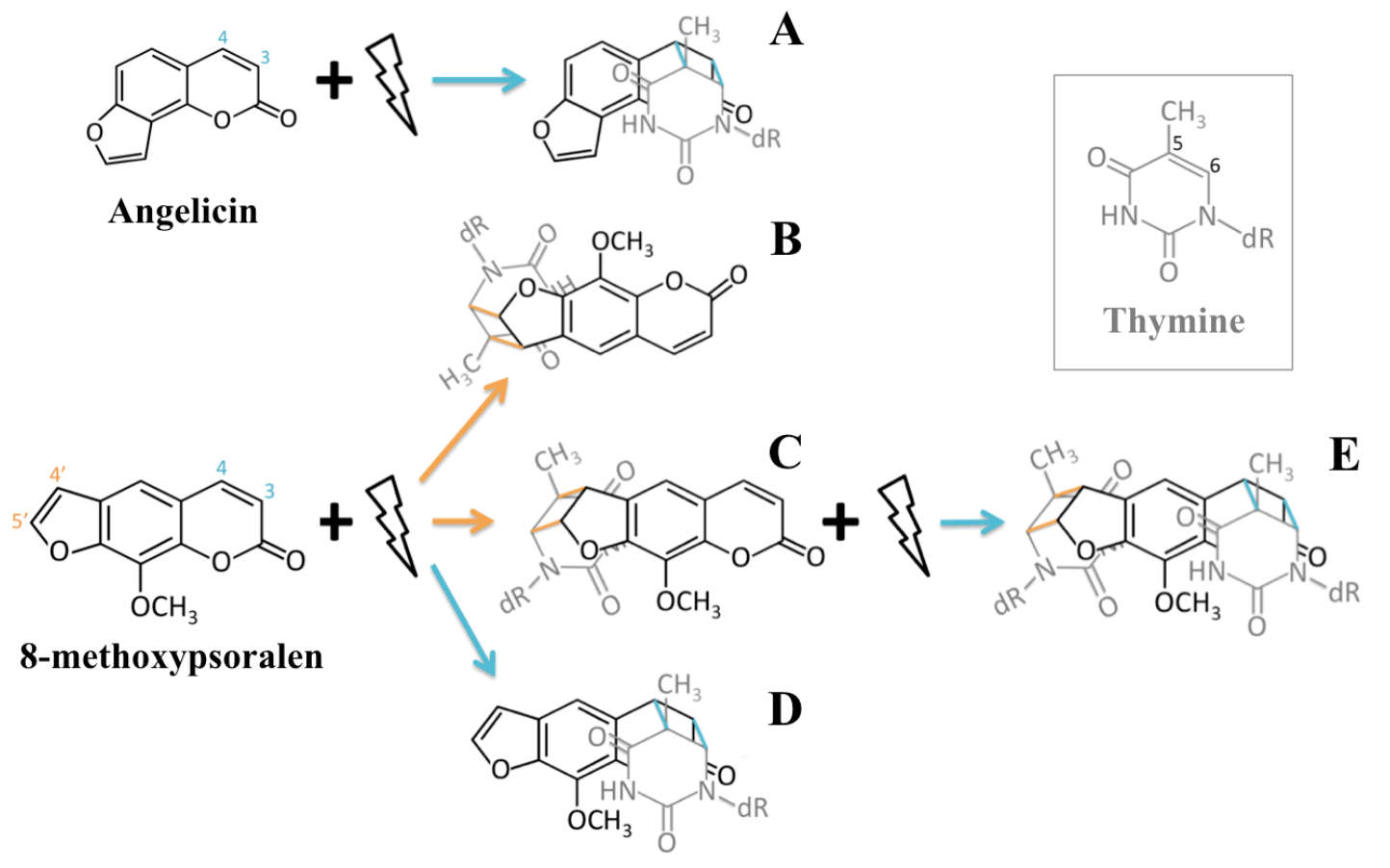

Figure 1.2. Angelicin and 8-methoxypsoralen are furocoumarin isomers that intercalate in DNA and preferentially bind to thymine bases in photocycloaddition reactions. 8methoxypsoralen differs from angelicin in that it is linear in structure and has a methoxy group at the 8-position. A) Angelicin pyrone-side monoadduct. Angelicin reacts with a single UVA photon to form a pyrone-side cyclobutane ring (blue) with thymine. B) 8methoxypsoralen furan-side monoadduct. 8-methoxypsoralen reacts with a single UVA photon to form a furan-side cyclobutane ring (orange) with thymine. C) 8methoxypsoralen furan-side monoadduct (diastereomer of B). D) 8-methoxypsoralen pyrone-side monoadduct. 8-methoxypsoralen reacts with a single UVA photon to form a pyrone-side cyclobutane ring with thymine. E) 8-methoxypsoralen interstrand cross-link. Structure $\mathbf{C}$ is the only monoadduct product that can result in DNA interstrand cross-link product when reacted with an additional UVA photon and adjacent thymine base.

To effectively compare the effects and cellular responses of monofunctional psoralens with bifunctional psoralens it is important to standardize the doses to ensure 
that comparable levels of damage are formed in each case. Using radioactively labeled psoralen and angelicin to quantify the respective levels of photoreaction of $E$. coli DNA, Borden et al. demonstrated that psorlen molecules photoreact with DNA about five times as frequently as angelicin molecules when drugs are used at equal concentration and cells are UVA-irradiated for 4-16 minutes (33). Additionally, some bifunctional psoralen isomers, such as 8-methoxypsoralen and amotosalen, produce different ratios of crosslinks and monoadducts in cells and this should be considered when comparing damage to angelicin-treated cells (43).

\section{DNA interstrand cross-link repair models}

DNA damage occurs frequently in cells and is caused by both endogenous and exogenous agents. In most cases, damage is confined to a single strand or base of DNA and can be repaired faithfully by enzymes that utilize the undamaged complementary strand as a template for resynthesis following incision of the damaged strand (44). However, DNA interstrand cross-links covalently link complementary strands and complicate, in theory, how cells could accurately repair this form of damage. A number of models have been proposed throughout the course of cross-link repair studies that each suggest the involvement of multiple repair pathways.

In early experiments in E. coli, the removal of bi-functional alkylation agents from DNA was detected by examining the alkylation products in E. coli DNA following

treatment with ${ }^{35} \mathrm{~S}$-labeled mustard gas via chromatographic analysis and suggested a possible cellular repair capacity for interstrand cross-links (45-47). Additionally, these studies demonstrated that a mutant strain incapable of removing thymine dimers from 
DNA was likewise incapable of removing mustard gas lesions. In mammalian L-cells, Reid and Walker (48) also demonstrated via chromatographic analysis that excision of cross-linked DNA occurred and proposed a two-step process of unhooking the damage to remove the product.

As a follow up to these studies, Cole (49) was able to show in alkaline sucrose sedimentation profiles that the DNA from $E$. coli cells treated with a psoralen derivative and UVA light was cut into discrete pieces following incubation periods and that mutant recA-cells did not exhibit the same joining products. This evidence, coupled with alkaline $\mathrm{CsCl}$ density profiles that showed fragmented DNA was joined with DNA strands of higher molecular weight in $r e c A+$ cells treated with psoralen and UVA but not $r e c A$ - cells, was interpreted to suggest that recombination events were involved in crosslink repair. Thus one of the early models for repair proposed that incisions surrounding the cross-link on one strand of DNA by the nucleotide excision repair pathway are followed by a recombinational reaction that utilizes a homologous template to accurately resynthesize over the partially incised cross-link (49). Van Houten et al. later demonstrated in vitro that incubating a site-specific psoralen cross-link with purified UvrABC excision nucleases produces dual incisions on a single strand of DNA surrounding the cross-link (50). The UvrABC excinuclease complex operates in the nuclease excision repair pathway in prokaryotes and is associated with the removal of a diverse range of base damage and monoadducts $(51,52)$. The results from studies by Cole and Van Houten taken together strongly supported the idea that nucleotide excision repair promoted the primary incision step of cross-link removal and this model remains 
prominent in the literature today. Be that as it may, the sequential repair events are still unclear.

In theory, after the initial incision event a cross-link would remain bound to the unincised DNA strand and prevent displacement of the damaged strand by helicases, such as UvrD. Similarly, a second round of excision repair operating directly on the incised region would lead to a double-strand break and result in a deletion of the sequences in the direct vicinity of the lesion. Thus, repair models invoked the idea that recombination may operate to recruit and provide an undamaged substrate that could be used as a template for the repair of this region. To examine how such a hypothetical substrate may be processed, Cheng et al. (53) used a biochemical approach involving a psoralenmonoadducted oligomer that was incubated with RecA, paired with a homologous region in a plasmid, and then UVA irradiated to form a three-stranded complex with a sitespecific cross-link. This complex was incubated with dNTPs, radioactively labeled dCTPs, and proteins involved in the nucleotide exicison repair pathway-UvrA, UvrB, UvrC, helicase II, DNA polymerase I, and DNA ligase—and then samples were restricted and electrophoresed on native acrylamide gel to show that the three-stranded complex was a viable substrate following the initial incision repair process. These experiments contributed to the development of a cross-link repair model that includes nucleotide excision repair pathway coupled with recombination (Figure 1.3A). Interestingly, the helicase II—UvrD in E. coli-has yet to be analyzed for its involvement in cross-link repair in vivo. The significant role UvrD plays in the turnover of UvrABC exinuclease complex during the repair of UV damage (54) makes the $u v r D$ gene product an interesting candidate for repair role of interstand cross-link damage. 
An issue raised by critics of the initial model pointed out that should the crosslink form in a region of the chromosome that has not yet been replicated no substrates for recombination would be available and faithful repair would not be possible. To address this, an alternative repair model was proposed and suggested that after initial incisions by the $\mathrm{ABC}$ excinuclease complex specialized translesion polymerases could replicate across the incised oligo-lesion product and provide a template for the second round of incisions (Figure 1.3B) (55). This idea was initially supported by a report that plasmids containing an interstrand cross-link displayed reduced survival when transformed into a polB- (polymerase II) mutant (56). Survival experiments in yeast cells demonstrated that rev3 mutants were sensitive to mitomycin $\mathrm{C}$ cross-links in stationary but not exponential phase (57), supporting the idea that an alternative repair pathway is involved when recombination products are not available as chromosome templates. Additionally, Zheng et al. observed mammalian cells that were defective in nucleotide excision repair and lesion bypass by PolH exhibited reduced repair of a site-specific mitomycin C cross-link in a reporter gene of a plasmid but that repair was complemented when transfected with a PolH expression vector (58). However, the potential role for translesion synthesis during cross-link repair in vivo has not been systematically examine in bacteria.

Beyond the initial incisions of interstrand cross-links by the UvrABC excinuclease complex alternative models for repair completion have proposed that the process advances through a double-strand break intermediate (Figure 1.3C) (59-63). While exploring this possibility, Kitayama et al. demonstrated by sedimentation profiles on neutral sucrose gradients that $D$. radiodurans treated with mitomycin $\mathrm{C}$ exhibited double-strand break structures in DNA (64). Additional support for this intermediate 
comes from mammalian studies, one of which detected the presence of double-strand breaks in DNA by running V79 cells treated with nitrogen mustard in plugs by pulse field gel electrophoresis (60). A potential role for double-strand break repair in the survival of cross-links has not been examined in E. coli.

In more recent studies with mammalian cells a number of base excision repair proteins have been shown to bind or incise interstrand cross-links (Figure 1.3D) and affect survival, although reports differ as to interpretation of the effects. An initial report found that in vitro, Endo VIII-like protein (NEIL1) could initiate repair on psoraleninduced monoadducts or cross-links in DNA substrates mimicking those encountered during the second round of incisions (65). However, others have reported that NEIL1 binding prevents the normal mechanism of incision and renders cells more resistant to interstrand cross-links when mutated $(35,66)$. Similarly, APE1 - the primary AP endonuclease in mammalian cells - has been reported to impede the normal processing of cisplatin-induced cross-links, and could lead to cisplatin resistance when mutated (27, 67). Finally, recent biochemical studies have suggested that NEIL3 promotes incision at psoralen interstrand cross-links and therefore promotes repair (26). However whether this occurs in vivo or affects cell survival was not determined.

Because most of these models lack in vivo evidence or characterization in bacterial cells, I have chosen to examine mutants from repair pathways previously implicated in order to determine which gene products are specifically involved in processing cross-links. In Chapter II I describe experiments using mutants from nucleotide excision repair, translesion synthesis, and double-strand break repair pathways 
and Chapter III I discuss the possible involvement of base excision repair proteins. All results are summarized and conclusions are discussed in Chapter IV.

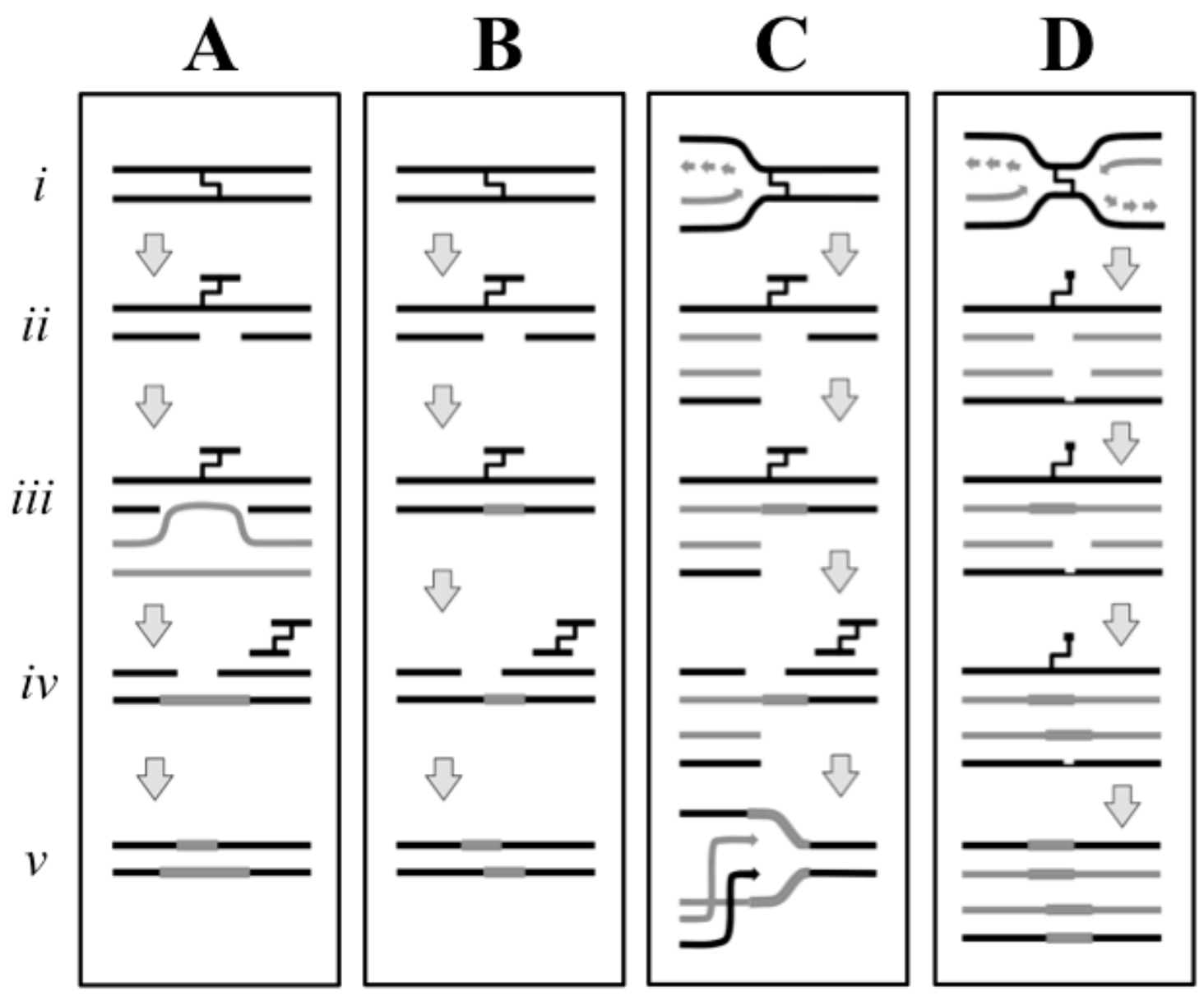

Figure 1.3. Prominent models for repair of DNA interstrand cross-links. A) Nucleotide excision repair and homologous recombination. The interstrand cross-link (i) is initially incised by the nucleotide excision repair complex (ii) before the gap on the incised strand is filled in by recombination using a sister chromosome (iii). Nucleotide excision repair could then, in theory, make a second round of incisions on the opposing strand (iv), which would be filled in using the 'newly formed' complementary strand as a template (v) (adapted from $(38,49,68)$ ). B) Nucleotide excision repair and translesion synthesis. The interstrand cross-link (i) is initially incised by the nucleotide excision repair complex (ii) before translesion synthesis filled in the gap (iii). Nucleotide excision repair then makes a second round of incisions to remove the lesion (iv) before the remaining gap is resynthesized using the 'newly formed' complementary strand as a template (v) (adapted from (55)). C) Excision-mediated double-strand break repair. Following an encounter with the replication fork (i), incision of the interstrand cross-link by nucleotide excision repair results in a double-strand break (ii). Translesion polymerases restore the incised template (iii) before a second round of nucleotide excision repair removes the cross-link 
and restores the template (iv). Recombination then repairs the double-strand break to restore the replication fork (v) (adapted from (60-62)). D) Base excision repair. Two replication forks converge on a cross-link (i) and a glycosylase creates an abasic site on one side of the damage (ii). Translesion polymerases synthesize over the abasic site (iii) as well as the unhooked cross-link (iv) and then the remaining single-stranded damage on the parent template is removed and resynthesized (v) (adapted from (26)).

\section{References}

1. Kohn KW (1996) Beyond DNA cross-linking: history and prospects of DNAtargeted cancer treatment-fifteenth Bruce F. Cain Memorial Award Lecture. Cancer research 56:5533-5546.

2. Lawley PD, Phillips DH (1996) DNA adducts from chemotherapeutic agents. Mutat Res 355(1-2):13-40.

3. Adair FE, Bagg HJ (1931) Experimental and clinical studies on the treatment of cancer by dichlorethylsulphide (mustard gas). Ann Surg 93(1):190-199.

4. Goldacre RJ, Loveless A, Ross WCJ (1949) Mode of production of chromosome abnormalities by the nitrogen mustards: the possible role of cross-linking. Nature 163:667-669.

5. Brookes P, Lawley PD (1960) The reaction of mustard gas with nucleic acids in vitro and in vivo. Biochem $J 77(3): 478-484$.

6. Travis LB et al. (1999) Risk of leukemia after platinum-based chemotherapy for ovarian cancer. $N$ Engl J Med 340(5):351-357.

7. Tucker MA, Coleman CN, Cox RS, Varghese A, Rosenberg SA (1988) Risk of second cancers after treatment for Hodgkin's disease. $N$ Engl J Med 318(2):76-81.

8. Akkari Y, Olson S (2004) Fanconi Anemia: A Decade of Discoveries. J Assoc Genet Technol 30(2):48-53.

9. Hashimoto S, Anai H, Hanada K (2016) Mechanisms of interstrand DNA crosslink repair and human disorders. Genes Environ 38:9.

10. Oostra AB, Nieuwint AW, Joenje H, de Winter JP (2012) Diagnosis of fanconi anemia: chromosomal breakage analysis. Anemia 2012:238731.

11. Cohen MM et al. (1982) The identification of fanconi anemia genotypes by clastogenic stress. Am J Hum Genet 34(5):794-810.

12. Sasaki MS, Tonomura A (1973) A high susceptibility of Fanconi's anemia to chromosome breakage by DNA cross-linking agents. Cancer Res 33(8):1829-1836.

13. Cheung RS, Taniguchi T (2017) Recent insights into the molecular basis of Fanconi anemia: genes, modifiers, and drivers. Int J Hematol 106(3):335-344.

14. Bhattacharjee S, Nandi S (2017) DNA damage response and cancer therapeutics through the lens of the Fanconi Anemia DNA repair pathway. Cell Commun Signal $15(1): 41$.

15. Kee Y, D'Andrea AD (2012) Molecular pathogenesis and clinical management of Fanconi anemia. J Clin Invest 122(11):3799-3806.

16. Gueiderikh A, Rosselli F, Neto JBC (2017) A never-ending story: the steadily growing family of the FA and FA-like genes. Genet Mol Biol 40(2):398-407. 
17. SM R (1993) Covalent structure of a nitrogen mustard-induced DNA interstrand cross-link: an N7-to-N7 linkage of deoxyguanosine residues at the duplex sequence 5'-d(GNC). Journal of the American chemical society

18. Rink SM, Hopkins PB (1995) A mechlorethamine-induced DNA interstrand crosslink bends duplex DNA. Biochemistry 34(4):1439-1445.

19. Guainazzi A, Campbell AJ, Angelov T, Simmerling C, Schärer OD (2010) Synthesis and molecular modeling of a nitrogen mustard DNA interstrand crosslink. Chemistry 16(40):12100-12103.

20. Roy U, Mukherjee S, Sharma A, Frank EG, Schärer OD (2016) The structure and duplex context of DNA interstrand crosslinks affects the activity of DNA polymerase $\eta$. Nucleic Acids Res 44(15):7281-7291.

21. Tomasz M et al. (1987) Isolation and Structure of a Covalent Cross-Link Adduct between Mitomycin C and DNA. Science 235(4793):1204-1208.

22. Hopkins PB MJT, Woo J, Weidner MF, Kirchner JJ, Sigurdsson ST, Raucher S (1991) Sequence Preferences of DNA Interstrand Cross-Linking Agents: Importance of Minimal DNA Structural Reorganization in the Cross-linking reaction of mechlorethamine, cisplatin, and mitomycin C. Tetrahedron 1415(47):2475-2489.

23. Rink SM, Lipman R, Alley SC, Hopkins PB, Tomasz M (1996) Bending of DNA by the mitomycin C-induced, GpG intrastrand cross-link. Chem Res Toxicol 9(2):382-389.

24. Musajo L, Rodighiero G (1970) Studies on the photo-C4-cyclo-addition reactions between skin-photosensitizing furocoumarins and nucleic acids. Photochemistry and photobiology 11(1):27-35.

25. Spielmann HP, Dwyer TJ, Hearst JE, Wemmer DE (1995) Solution structures of psoralen monoadducted and cross-linked DNA oligomers by NMR spectroscopy and restrained molecular dynamics. Biochemistry 34(40):12937-12953.

26. Semlow DR, Zhang J, Budzowska M, Drohat AC, Walter JC (2016) ReplicationDependent Unhooking of DNA Interstrand Cross-Links by the NEIL3 Glycosylase. Cell 167(2):498-511.e14.

27. Kothandapani A et al. (2011) Novel role of base excision repair in mediating cisplatin cytotoxicity. J Biol Chem 286(16):14564-14574.

28. Dusre L, Covey JM, Collins C, Sinha BK (1989) DNA damage, cytotoxicity and free radical formation by mitomycin $\mathrm{C}$ in human cells. Chem Biol Interact 71(1):63-78.

29. Kanne D, Straub K, Rapoport H, Hearst JE (1982) Psoralen-deoxyribonucleic acid photoreaction. Characterization of the monoaddition products from 8methoxypsoralen and 4,5'8-trimethylpsoralen. Biochemistry 21(5):861-871.

30. Tessman JW, Isaacs ST, Hearst JE (1985) Photochemistry of the furan-side 8methoxypsoralen-thymidine monoadduct inside the DNA helix. Conversion to diadduct and to pyrone-side monoadduct. Biochemistry 24(7):1669-1676.

31. Saffran WA, Cantor CR (1984) Mutagenic SOS repair of site-specific psoralen damage in plasmid pBR322. J Mol Biol 178(3):595-609.

32. Kaye J, Smith CA, Hanawalt PC (1980) DNA repair in human cells containing photoadducts of 8-methoxypsoralen or angelicin. Cancer Res 40(3):696-702. 
33. Bordin F, Carlassare F, Baccichetti F, Anselmo L (1976) DNA repair and recovery in Escherichia coli after psoralen and angelicin photosensitization. Biochim Biophys Acta 447(3):249-259.

34. Mogi S, Oh DH (2006) gamma-H2AX formation in response to interstrand crosslinks requires XPF in human cells. DNA Repair (Amst) 5(6):731-740.

35. McNeill DR et al. (2013) NEIL1 responds and binds to psoralen-induced DNA interstrand crosslinks. J Biol Chem 288(18):12426-12436.

36. Bordin F, Marciani S, Baccichetti FR, Dall'Acqua F, Rodighiero G (1975) Studies on the photosensitizing properties of angelicin, an angular furocoumarin forming only monofunctional adducts with the pyrimidine bases of DNA. Ital J Biochem 24(5):258-267.

37. Ashwood-Smith MJ, Grant E (1977) Conversion of psoralen DNA monoadducts in E. coli to interstrand DNA cross links by near UV light (320-360 nm): Inability of angelicin to form cross links, in vivo. Experientia 15;33(3):384-386.

38. Dall'Acqua F, Marciani S, Ciavatta L, Rodighiero G (1971) Formation of interstrand cross-linkings in the photoreactions between furocoumarins and DNA. $Z$ Naturforsch B 26(6):561-569.

39. Smith SI, Brodbelt JS (2010) Rapid characterization of cross-links, mono-adducts, and non-covalent binding of psoralens to deoxyoligonucleotides by LC-UV/ESIMS and IRMPD mass spectrometry. Analyst 135(5):943-952.

40. Sage E, Moustacchi E (1987) Sequence context effects on 8-methoxypsoralen photobinding to defined DNA fragments. Biochemistry 26(12):3307-3314.

41. Musajo L, Rodighiero G (1972) Mode of photosensitizing action of furocoumarins. Photophysiology (7):115-147.

42. Kanne D, Straub K, Hearst JE, Rapoport H (1982) Isolation and Characterization of Pyrimidine-Psoralen-Pyrimidine Photodiadducts from DNA. J Am Chem Soc 104:6754-6764.

43. Lai C et al. (2008) Quantitative analysis of DNA interstrand cross-links and monoadducts formed in human cells induced by psoralens and UVA irradiation. Anal Chem 80(22):8790-8798.

44. Sancar A, Lindsey-Boltz LA, Unsal-Kaçmaz K, Linn S (2004) Molecular mechanisms of mammalian DNA repair and the DNA damage checkpoints. Annu Rev Biochem 73:39-85.

45. Lawley PD, Brookes P (1965) Molecular mechanism of the cytotoxic action of difunctional alkylating agents and of resistance to this action. Nature 206(983):480483.

46. Kohn KW, Steigbigel NH, Spears CL (1965) Cross-linking and repair of DNA in sensitive and resistant strains of E. coli treated with nitrogen mustard. Proc Natl Acad Sci U S A 53(5):1154-1161.

47. Venitt S (1968) Interstrand cross-links in the DNA of Escherichia coli B/r and B s-1 and their removal by the resistant strain.

48. Reid BD WIG (1968) The response of mammalian cells to alkylating agents II. On the mechanism of the removal of sulfar-mustard-induced cross-links. Biochimica Et biophysica acta 179(1):179-188.

49. Cole RS (1973) Repair of DNA containing interstrand crosslinks in Escherichia 
coli: sequential excision and recombination. Proc Natl Acad Sci U S A 70(4):10641068.

50. Van Houten B, Gamper H, Holbrook SR, Hearst JE, Sancar A (1986) Action mechanism of $\mathrm{ABC}$ excision nuclease on a DNA substrate containing a psoralen crosslink at a defined position. Proc Natl Acad Sci U S A 83(21):8077-8081.

51. Setlow RB, Carrier WL (1963) The disappearance of thymine dimers from DNA: an error-correcting mechanism. 1963. DNA Repair (Amst) 2(11):1274-1279.

52. Boyce RP, Howard-Flanders P (1964) Release of ultraviolet light-induced thymine dimers from DNA in E. coli K-12. 1964. DNA Repair (Amst) 2(11):1280-1287.

53. Cheng S, Van Houten B, Gamper HB, Sancar A, Hearst JE (1988) Use of psoralenmodified oligonucleotides to trap three-stranded RecA-DNA complexes and repair of these cross-linked complexes by ABC excinuclease. $J$ Biol Chem 263(29):15110-15117.

54. Caron PR, Kushner SR, Grossman L (1985) Involvement of helicase II (uvrD gene product) and DNA polymerase I in excision mediated by the uvrABC protein complex. Proc Natl Acad Sci U S A 82(15):4925-4929.

55. Berardini M, Mackay W, Loechler EL (1997) Evidence for a recombinationindependent pathway for the repair of DNA interstrand cross-links based on a sitespecific study with nitrogen mustard. Biochemistry 36(12):3506-3513.

56. Berardini M, Foster PL, Loechler EL (1999) DNA polymerase II (polB) is involved in a new DNA repair pathway for DNA interstrand cross-links in Escherichia coli. $J$ Bacteriol 181(9):2878-2882.

57. McHugh PJ, Sones WR, Hartley JA (2000) Repair of intermediate structures produced at DNA interstrand cross-links in Saccharomyces cerevisiae. Molecular and cellular ... 20(1):3425-3433.

58. Zheng $\mathrm{H}$ et al. (2003) Nucleotide Excision Repair- and Polymerase -Mediated Error-Prone Removal of Mitomycin C Interstrand Cross-Links. Molecular and Cellular Biology 23(2):754-761.

59. Sczepanski JT, Jacobs AC, Van Houten B, Greenberg MM (2009) Double-strand break formation during nucleotide excision repair of a DNA interstrand cross-link. Biochemistry 48(32):7565-7567.

60. De Silva IU, McHugh PJ, Clingen PH, Hartley JA (2000) Defining the roles of nucleotide excision repair and recombination in the repair of DNA interstrand cross-links in mammalian cells. Mol Cell Biol 20(21):7980-7990.

61. Bessho T (2003) Induction of DNA replication-mediated double strand breaks by psoralen DNA interstrand cross-links. J Biol Chem 278(7):5250-5254.

62. Niedernhofer LJ et al. (2004) The structure-specific endonuclease Ercc1-Xpf is required to resolve DNA interstrand cross-link-induced double-strand breaks. $\mathrm{Mol}$ Cell Biol 24(13):5776-5787.

63. Peng X, Ghosh AK, Van Houten B, Greenberg MM (2010) Nucleotide excision repair of a DNA interstrand cross-link produces single- and double-strand breaks. Biochemistry 49(1):11-19.

64. Kitayama S, Asaka S, Totsuka K (1983) DNA double-strand breakage and removal of cross-links in Deinococcus radiodurans. J Bacteriol 155(3):1200-1207.

65. Couvé S, Macé-Aimé G, Rosselli F, Saparbaev MK (2009) The human oxidative 
DNA glycosylase NEIL1 excises psoralen-induced interstrand DNA cross-links in a three-stranded DNA structure. J Biol Chem 284(18):11963-11970.

66. Macé-Aimé G, Couvé S, Khassenov B, Rosselli F, Saparbaev MK (2010) The Fanconi anemia pathway promotes DNA glycosylase-dependent excision of interstrand DNA crosslinks. Environ Mol Mutagen 51(6):508-519.

67. Sawant A et al. (2017) Differential role of base excision repair proteins in mediating cisplatin cytotoxicity. DNA Repair (Amst) 51:46-59.

68. Sladek FM, Munn MM, Rupp WD, Howard-Flanders P (1989) In vitro repair of psoralen-DNA cross-links by RecA, UvrABC, and the 5'-exonuclease of DNA polymerase I. J Biol Chem 264(12):6755-6765. 
Chapter II. Limited capacity or involvement of excision repair, double-strand breaks, or translesion synthesis for psoralen cross-link repair in Escherichia coli

\begin{abstract}
DNA interstrand cross-links are complex lesions that covalently bind complementary strands of DNA and whose mechanism of repair remains poorly understood. In Escherichia coli, several gene products have been proposed to be involved in cross-link repair based on the hypersensitivity of mutants to cross-linking agents. However, crosslinking agents induce several forms of DNA damage, making it challenging to attribute mutant hypersensitivity specifically to interstrand cross-link damage. To address this, we compared the survival of UVA-irradiated mutants in the presence of 8methoxypsoralen — which forms interstrand cross-links and monoadducts - to that of angelicin - a congener forming only monoadducts. We show that incision by nucleotide excision repair is not required for resistance to interstrand cross-links. In addition, neither RecN nor DNA Polymerases II, IV, or V is required for interstrand cross-link survival, argument against models proposing that double-strand break intermediates or translesion polymerases participate in the repair process. Finally, estimates based on Southern analysis of DNA fragments in alkali agarose gels indicate that lethality occurs in wild type cells at doses producing as few as one interstrand cross-links per genome. These observations suggest that $E$. coli lacks an efficient repair mechanism for this form of damage.
\end{abstract}

\title{
Introduction
}


DNA interstrand cross-links are highly cytotoxic lesions induced by a variety of bifunctional agents, including nitrogen mustard, cisplatin, mitomycin $\mathrm{C}$, and psoralen plus UVA light (1-5). Cytotoxicity is thought to result from the covalent linkage between both DNA strands preventing strand separation and thus inhibiting essential processes like replication or transcription at these sites $(2,6)$. Cross-linking agents are widely used as chemotherapeutics and have been effectively employed in the treatment of a range of hyperplastic or dysplastic conditions such as psoriasis or white leprosy, respectively (710). Their effectiveness in treating these disease states has led to an interest in understanding how these medically relevant lesions are processed by cells with the goal of developing novel targets or strategies for chemotherapeutics.

Although several genes have been isolated that, when mutated, render cells hypersensitive to cross-linking agents (11-13), many aspects of how these complex lesions are repaired and processed in cells remain unknown. Additionally, all crosslinking agents induce multiple forms of DNA damage, making it difficult to attribute mutant hypersensitivity specifically to defective repair of the cross-link lesion $(5,14-17)$. Various models for interstrand cross-link repair have been proposed, each involving multiple repair pathways that couple components of nucleotide excision repair with recombination, translesion synthesis, or alternative nuclease complexes (18-21). However, after the initial incision event, all of these models remain highly speculative and are hampered by the challenges of reconstituting this multi-step, multi-pathway repair process.

Based on early experiments in E. coli, researchers recognized the challenge of repairing a DNA interstrand cross-link due to the covalent attachment of this adduct to 
both DNA strands. Researchers inferred that repair would likely require the sequential action of multiple pathways $(12,22,23)$. The hypersensitivity of nucleotide excision repair and recombination mutants, $u v r A$ and $r e c A$, respectively, suggested that nucleotide excision repair may initiate incisions on one strand and that recombination from a sister chromosome would then provide an undamaged template to replace the incised region. A second round of incisions by nucleotide excision repair could then complete the repair process. In support of this model, biochemical studies found that the UvrABC nucleotide excision repair complex would recognize and incise one strand of a cross-link in vitro (18). Other studies demonstrated that RecA could promote strand exchange at this site in vitro if the gapped region were first expanded through exonucleolytic degradation (24). Although the mechanisms suggested by this model could in principle repair a cross-link, it should be noted that $u v r A$ and $r e c A$ mutants are hypersensitive to almost all forms of DNA damage, not just cross-links. And currently, no intermediates for the events following the initial incision have been characterized or observed in vivo.

A feature common to most models to DNA interstrand cross-link repair is that the process is initiated by the nucleotide excision repair pathway—-the primary pathway by which a diverse range of base damage and monoadducts are repaired $(25,26)$. In E. coli, UvrA, UvrB, and UvrC form an excinuclease that makes dual incisions surrounding a DNA lesion on the damage-containing strand (27). Cells deficient in any one of these gene products fail to make incisions and exhibit elevated levels of recombination, genomic rearrangements, and cell lethality (28-31). UvrD is a helicase that promotes removal of the incised oligo and releases the exinuclease complex from DNA before DNA polymerase I fills in the gap and DNA ligase seals the nick to complete repair (32- 
34). In the absence of $\mathrm{UrD}$ the excinuclease complex remains bound to the initial adduct and cells are almost as hypersensitive and defective at removing lesions from the genome as those lacking UvrA, UvrB, or UvrC (35)(36).

Several in vitro studies suggest that nucleotide excision repair proteins act to initiate the processing of interstrand cross-links and in vivo studies have shown that $u v r A$, $u v r B$, and, $u v r C$ mutants are hypersensitive to DNA interstrand cross-linking agents and fail to incise cross-links $(18,23,24,37-41)$. Cho, an alternative nuclease with homology to UvrC has also recently been shown to contribute to survival in the presence of 8methoxypsoralen, perhaps by enhancing the rate of the initial incision $(41,42)$. However, the role of UvrD in interstrand cross-link repair has not yet been examined in vivo. It has been postulated that UvrD may displace a cross-linked structure following the initial incision event by UvrABC complex so that the gap could be filled in by a translesion polymerase $(18,43)$. What complicates this is that $\mathrm{UvrD}$ is required for exinuclease turnover at monoadducts and turnover may still be required to allow further cross-link repair events to occur (34). It is possible that UvrD may also be required for strand displacement following the second round of incisions of an unhooked cross-link.

Other models noted that DNA cross-links occurring in nonreplicating cells or in unreplicated regions of the genome would not have a sister chromosome available for recombination $(19,44)$. To account for this, it was proposed that alternative DNA polymerases might replicate across the incised oligo-lesion product to provide a template for the second round of incisions. Support for this idea came from early reports that plasmids containing an interstrand cross-link displayed reduced survival when transformed into a pol B (Polymerase II) mutant (44). However, several labs have since 
been unable to verify a range of phenotypes reported for this polB strain (44-46), implying the effect may have been to secondary mutation within this particular strain (47-49). A later biochemical study also showed that PolV, the $\operatorname{din} B$ gene product, could synthesize through templates containing an unhooked oligo-bound cross-link in vitro, supporting the possibility that translesion synthesis could carry out this hypothetical step in cells (49). However, to date the potential role for translesion synthesis during crosslink repair in vivo has not been systematically examined in bacteria.

A third model for the repair of cross-links comes from studies in mammalian cells and suggests that repair is coupled to replication and proceeds through a double-strand break intermediate $(50-52)$. In this model, interstrand cross-links that block replication forks are incised by the Fanconi anemia pathway/nucleotide excision repair proteins (ERCC1/XPF endonuclease) as well as other structure-specific nucleases and result in double-strand break intermediates. Consistent with this, double-strand breaks are detected in both yeast and mammalian cells following treatment with interstrand cross-linking agents and double-strand repair mutants are hypersensitive to these drugs (50-52). Similarly, the bacterial UvrABC excinuclease has been shown capable of incising both strands of an interstrand cross-link in vitro $(53,54)$. However, whether double-strand breaks arise in vivo during the bacterial repair process has not been directly examined.

To further characterize the pathways and gene products involved in the repair of DNA interstrand cross-links, we compared the survival of $E$. coli cultures irradiated with UVA in the presence of 8-methoxypsoralen or angelicin. The comparison between these two isomers allows us to differentiate between genes products that are involved in the general repair of monoadducts from those that have a specific or concurrent role in cross- 
link repair (55). 8-methoxypsoralen is a linear molecule capable of forming DNA monoadducts and interstrand cross-links whereas angelicin has an angular structure that only allows it to produce monoadducts $(4,41,56,57)$. Using this approach, mutants lacking gene products that specifically contribute to the repair of interstrand cross-links would be expected to exhibit greater sensitivity to 8-methoxypsoralen-induced damage relative to angelicin-induced damage when compared to the sensitivity of wild type cultures (55). Here, we examined several candidate mutants from pathways that have been proposed to be involved in the repair of cross-links based on current models in bacteria or mammals.

\section{Methods}

Bacterial Strains. The parent strain used in this study is SR108, a thyA36 deoC2 derivative of W3110 (58). Isogenic strains lacking uvrA (HL952), uvrD (CL1302), polB $\operatorname{din} B$ umuDC (CL646) were constructed using standard P1 transduction methods that have been described previously $(48,59)$. CL912 (DY329 recN::cat) was constructed using the recombineering strain DY329 (60). The chloramphenicol resistance gene was amplified from TP507 (61) using PCR primers recNF-catF 5'GTAATGGTTTTTCATACAGGAAAACGACTATGTTGGCACAATGAGACGTTG ATCGGCAC, and recNR-catR 5'GCAGGAAAAAAGTTTACGCTGCAAGCAGTTCTTTCGCATTCTTTCGAATTTC TGCCATT. PCR product was then transformed into DY329 to generate CL912, selecting for chloramphenicol resistance. The gene replacement was transferred into SR108 using standard P1 transduction to generate CL915 (SR108 recN::cat). 
Psoralen-UVA and Angelcin-UVA Survival Assays. Fresh overnight cultures were diluted 1:100 in Davis medium (62) supplemented with $0.4 \%$ glucose, $0.2 \%$ Casamino Acids, and $10 \mu \mathrm{g} / \mathrm{mL}$ thymine (DGCthy) and grown at $37^{\circ} \mathrm{C}$ to an optical density of 0.4 at 500nm (OD600). At this time, $10 \mu \mathrm{g} / \mathrm{mL}$ of 8-methoxypsoralen (Acros Organics, item 298-81-7) or $40 \mu \mathrm{g} / \mathrm{mL}$ of angelicin (Sigma-Aldrich, item A0956) was added to the cultures and incubation continued for $10 \mathrm{~min}$. Cells were then irradiated using two 32watt UVA bulbs (Sylvania) with a peak emittance of $320 \mathrm{~nm}$ at an incident dose of 6.3 $\mathrm{J} / \mathrm{m}^{2} / \mathrm{s}$. Angelicin-treated cells were UVA-irradiated for longer time increments than 8methoxypsoralen-treated cells in order to achieve comparable kill curves for wild type cells in either condition. At the times indicated, $100-\mu \mathrm{L}$ aliquots were removed from each culture and serially diluted in 10 -fold increments. Triplicate $10-\mu \mathrm{L}$ aliquots of each dilution were spotted on Luria-Bertani agar plates supplemented with $10 \mu \mathrm{g} / \mathrm{mL}$ thymine (LBthy) and incubated at $37^{\circ} \mathrm{C}$. Viable colonies were counted the next day to determine the surviving fraction. The lethal dose in 8-methoxypsoralen-treated cultures was determined based on the Poisson expression, $\mathrm{P}(\mathrm{i})=\mathrm{x}^{\mathrm{i}} \mathrm{e}^{-\mathrm{x}} / \mathrm{i}$ !, as the fraction of surviving cells (those have zero lethal lesions) at a dose where cells in the population have an average of 1 lethal lesion; $\mathrm{i}=0, \mathrm{x}=1$.

In vivo detection of DNA interstrand cross-links. Cultures containing the plasmid pBR322 were grown overnight at $37^{\circ} \mathrm{C}$ in DGCthy medium supplemented with $50 \mu \mathrm{g} / \mathrm{mL}$ of ampicillin. A $0.1-\mathrm{mL}$ aliquot from this culture was pelleted and resuspended in 10-mL 
DGCthy medium without ampicillin and grown in a $37^{\circ} \mathrm{C}$ shaking water bath until grown to an OD600 of 0.4 .

Cultures used for the incision/recovery assay were exposed to $20 \mu \mathrm{g} / \mathrm{mL} 8$ methoxypsoralen for $10 \mathrm{~min}$ at $37^{\circ} \mathrm{C}$ and subsequently irradiated with a UVA dose of 5.7 $\mathrm{kJ} / \mathrm{m}^{2}$. Irradiated cultures were then incubated for a recovery period of $120 \mathrm{~min}$ where 0.75-mL aliquots were collected at times indicated and then transferred to an equal volume of ice-cold 4X NET buffer (10mM Tris [pH 8.0], 40mM EDTA, 400mM NaCl).

Cultures used for the dose-dependent induction of cross-links were exposed to 10 $\mu \mathrm{g} / \mathrm{mL}$ of 8 -methoxypsoralen for $10 \mathrm{~min}$ at $37^{\circ} \mathrm{C}$ and UVA irradiated. Aliquots of 0.75 $\mathrm{mL}$ were collected during the course of the UVA treatment at the doses indicated and transferred to an equal volume of ice-cold $4 \mathrm{X}$ NET buffer.

Cells were pelleted, resuspended in $130-\mu \mathrm{L}$ lysis buffer $(1 \mathrm{mg} / \mathrm{mL}$ lysozyme, 0.5 $\mathrm{mg} / \mathrm{mL}$ RNaseA in $10 \mathrm{mM}$ Tris, $1 \mathrm{mM}$ EDTA [pH 8.0]), and incubated at $37^{\circ} \mathrm{C}$ for 30 min. Then, $10-\mu \mathrm{L}$ of $10 \mathrm{mg} / \mathrm{mL}$ proteinase $\mathrm{K}$ and $10-\mu \mathrm{L}$ of $20 \%$ Sarkosyl were added to the samples and incubation continued for 1 hour at $37^{\circ} \mathrm{C}$. Samples were extracted with four volumes of phenol-chloroform, followed by two volumes of chloroform and then dialyzed against 200-mL of $1 \mathrm{mM}$ Tris ( $\mathrm{pH} 8.0)$ and $1 \mathrm{mM}$ EDTA for 45 min using 47mm Millipore $0.025-\mu \mathrm{M}$ pore disks. The DNA was digested with HindIII (Thermo Fisher) overnight at $37^{\circ} \mathrm{C}$. Samples were electrophoresed on a $0.75 \%$ alkaline agarose gel in $30 \mathrm{mM} \mathrm{NaOH}, 1 \mathrm{mM}$ EDTA at $1 \mathrm{~V} / \mathrm{cm}$ for 16 hours. DNA in the gels was then transferred to Hybond N+ nylon membranes (GE Healthcare) using standard Southern blotting techniques. The plasmid DNA was detected by probing with ${ }^{32} \mathrm{P}$-labeled pBR322 that was prepared by nick translation (Roche) using alpha ${ }^{32} \mathrm{P}-\mathrm{dCTP}>6000 \mathrm{Ci} / \mathrm{mmol}$ 
(Perkin-Elmer). Southern blots were visualized using a Storm 840 phosphorimager (GE Biosciences) and its associated ImageQuant analysis software.

The fraction of 8-methoxypsoralen cross-links formed at each time point was calculated as the ratio of DNA band running at about twice the molecular weight of the linear band to the total DNA per lane and normalized to the fraction of cross-links in untreated samples.

Fraction of cross-linked plasmid $=\left(\mathrm{XD}_{\text {time }(\mathrm{x})} / \mathrm{TD}_{\text {time(x) }}\right)-\left(\mathrm{XD}_{\text {untreated }} / \mathrm{TD}_{\text {untreated }}\right)$, where XD represents cross-linked DNA and TD represents total DNA.

The best-fit line for the fraction of lesion-free plasmid was calculated from the Poisson distribution based on the assumption that two photons must be absorbed to form a cross-link (40) (23) (63), where $y=P_{(0)}+P_{(1)}=e^{-(m) x}+(m) x e^{-(m) x}$.

\section{Results}

$u v r D$ mutants are hypersensitive to monoadducts but are almost as resistant as wild type cells when both monoadducts and cross-links are present

To investigate the role of nucleotide excision repair enzyme UvrD in the processing of cross-links, we examined the survival of $u v r D$ mutants following UVA irradiation in the presence of either 8-methoxypsoralen or angelicin. A previous study by Bordin et al. has shown that psoralen and angelicin photoreact with DNA in E. coli at a ratio of about 5:1 when irradiated with equal drug concentrations and doses of UVA light (56) whereas 8-methoxypsoralen forms adducts in native DNA at a ratio of about 4:1 compared to angelicin (64). Therefore we chose to treat cells with $10 \mu \mathrm{g} / \mathrm{mL} 8$ methoxypsoralen or $40 \mu \mathrm{g} / \mathrm{mL}$ angelicin in order to induce a comparable number of 
lesions in either treatment. Under these conditions, the survival of wild type cultures in the presence of angelicin was reduced by more than two orders of magnitude within 12 $\mathrm{kJ} / \mathrm{m}^{2}$ of UVA irradiation (Figure 2.1A). Alternatively, a loss of viability of the same magnitude was observed within $3 \mathrm{~kJ} / \mathrm{m}^{2}$ in wild type cells treated with 8 -

methoxypsroalen, consistent with the high lethality associated with the formation of DNA interstrand cross-links (Figure 2.1B). By comparison, uvrA mutants were hypersensitive to both angelicin and 8-methoxysproalen, with survival decreasing greater than two orders of magnitude after $1 \mathrm{~kJ} / \mathrm{m}^{2} \mathrm{UVA}$ irradiation in each case.
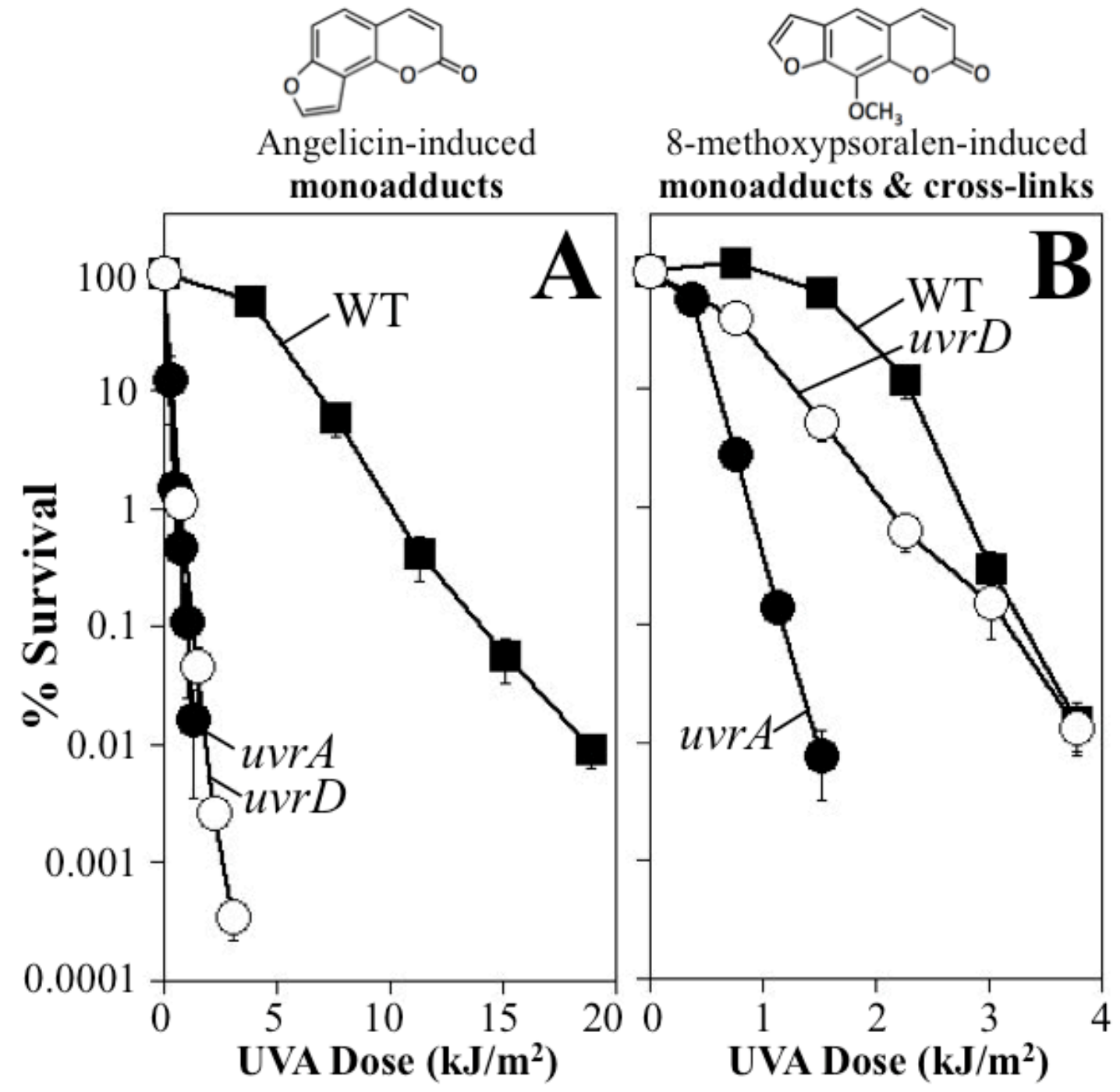
Figure 2.1. UvrD contributes to survival in the presence of monoadducts but not DNA interstrand cross-links. The survival of WT (Filled squares), uvrA (filled circles), and $u v r D$ (open circles) mutants following UVA irradiation in the presence of A) $40 \mu \mathrm{g} / \mathrm{mL}$ angelicin or B) $10 \mu \mathrm{g} / \mathrm{mL} 8$-methoxypsoralen is plotted. Plots represent the average of at least 4 experiments. Error bars represent standard error of the mean.

When we examined $u v r D$ cultures under the same conditions, we observed that these mutants were nearly as hypersensitive to angelicin-induced monoadducts as $u v r A$ mutants (Figure 2.1A), consistent with what has been observed for other forms of base damage and monoadducts such as pyrimidine dimers and $\mathrm{N}$-acetoxy-N2acetylaminofluorene (65-67). However, $u v r D$ mutants treated with 8-methoxypsoralen required over $2 \mathrm{~kJ} / \mathrm{m}^{2} \mathrm{UVA}$ irradiation to reduce survival by two orders of magnitude. At this dose, $u v r D$ mutants exhibit a nearly wild type-like resistance. Two inferences can be made from this observation: First, the comparable resistance of wild type and $u v r D$ mutants implies that UvrD does not contribute to interstrand cross-link repair. If the nucleotide excision repair complex initiates incisions at cross-links, one can infer that UvrD is not required for either oligo removal or excinuclease turnover during the first incision, nor would it be required if a second round of incisions occurs as postulated in many models such as those shown in Figure 1. Second, it is notable that $u v r D$ mutants are hypersensitive in the presence of monoadducts (Figure 2.1A), but as resistant as wild type cells when both monoadducts and interstrand cross-links are present. This allows us to infer that the lethality observed in wild type cells is caused almost exclusively by the presence of DNA interstrand cross-links. Thus, although 8-methoxypsoralen monoadducts are formed at higher frequencies than interstrand cross-links, wild type 
cultures are able to efficiently repair and survive in the presence of the former lesion and lethality results from the presence of interstrand cross-links.

The nearly normal resistance of $u v r D$ mutants to interstrand cross-links might suggest that incision occurs normally in these mutants. To examine this as a possibility, we compared the rate that interstrand cross-links were incised in wild type cells compared to $u v r A$ and $u v r D$ mutants. To this end, cultures containing pBR322 were treated with 8-methoxypsoralen and UVA light and then allowed to recover. At various times during the recovery period, total genomic and plasmid DNA was purified from aliquots of the cultures. The purified DNA was the restricted with HindIII to linearize the plasmid and examined by Southern analysis following alkali denaturing agarose gel electrophoresis to determine the rate that DNA interstrand cross-links were incised over time (Figure 2.2A). In wild type cultures immediately following $5.7 \mathrm{~kJ} / \mathrm{m}^{2}$ of UVA irradiation, $3.6 \%$ of the plasmids contained a DNA interstrand cross-link. The fraction of DNA migrating in the cross-link region of the gel decreased over the recovery period, with more that three quarters of the cross-links being incised by the end of the 120minute time course (Figure 2.2B). In $u v r A$ mutants, $7.9 \%$ of the molecules initially contained cross-links following UVA irradiation at the same dose. In these cultures, incisions of cross-links were severely impaired, as most cross-links persisted in the DNA throughout the 120-minute recovery period, consistent with previous studies showing defective incisions in these mutants. Surprisingly, although $u v r D$ cultures are almost as resistant to cross-links as wild type cultures, the mutants were impaired in their ability to make incisions, similar to $u v r A$ mutants. This observation implies that although 
nucleotide excision repair proteins may be involved in the removal of cross-links, these incisions are not necessarily productive.
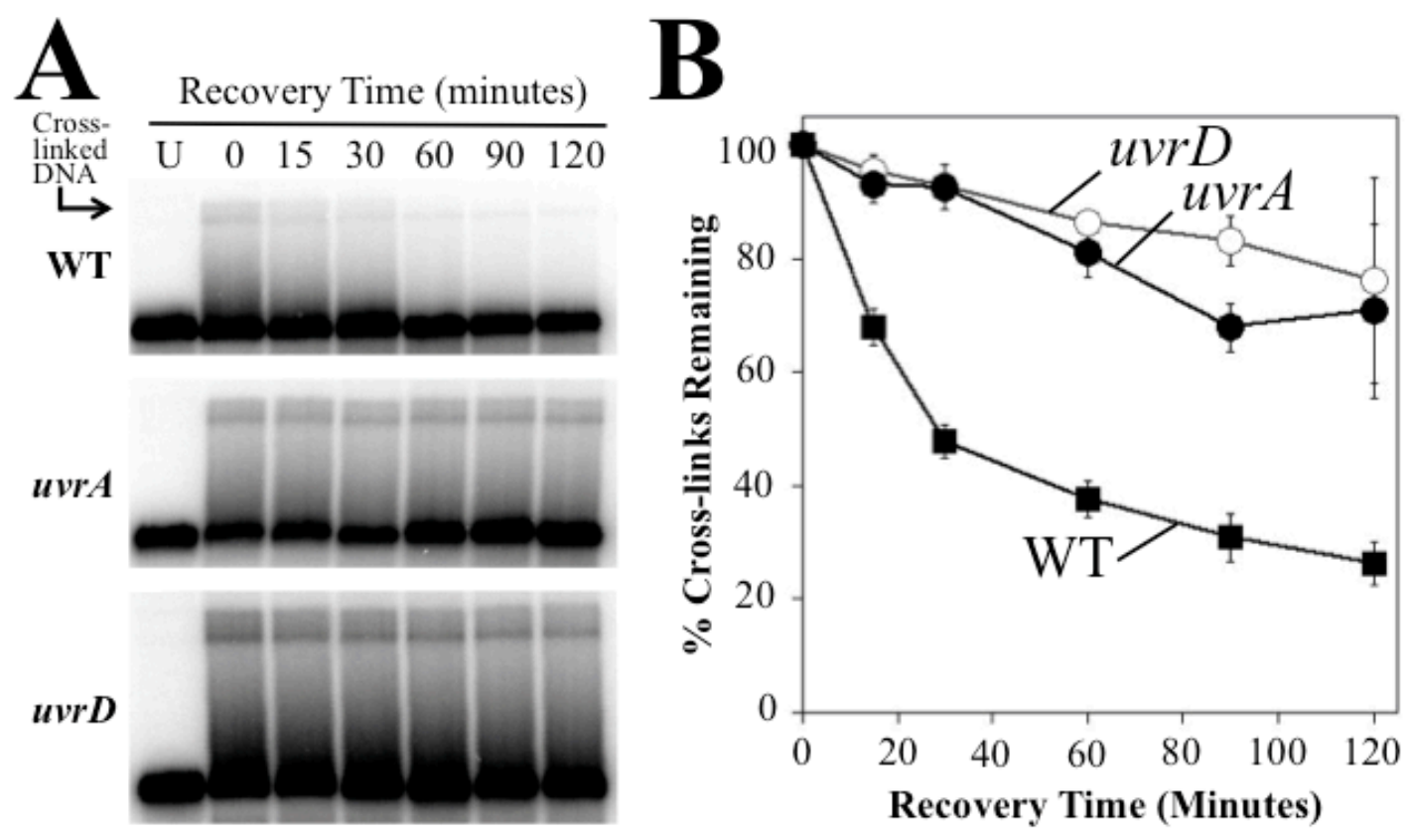

Figure 2.2. $u v r D$ mutants have diminished capacity for incising DNA interstrand crosslinks. A) Cultures containing the plasmid pBR322 were UVA-irradiated with $5.7 \mathrm{~kJ} / \mathrm{m}^{2}$ in the presence of $20 \mu \mathrm{g} / \mathrm{mL} 8$-methoxypsoralen and then allowed to recovery for 120minutes. To observe the cross-links remaining in the DNA at each time-point, total genomic and plasmid DNA was purified from cells, restricted with HindIII to linearize the plasmid, and examined by Southern analysis following alkali gel electrophoresis using ${ }^{32} \mathrm{P}$-labeled pBR322 as probe. B) The fraction of cross-links remaining in the DNA over the recovery period is plotted for WT (filled squares), $u v r A$ (filled circles), and $u v r D$ (open circles). The initial percentage of cross-linked plasmids immediately following UVA irradiation were as follows: WT, $3.6 \pm 1.0 \%$; $u v r A, 7.9 \pm 2.3 \%$; and $u v r D 6.6 \pm$ $0.7 \%$. Plots represent the average of 7 experiments for WT and 4 experiments for $u v r A$ and $u v r D$ mutants. Error bars represent standard error of the mean.

\section{Translesion DNA polymerases do not contribute to survival in the presence of}

\section{interstrand cross-links}


Following the initial incisions by nucleotide excision repair, models in both bacteria and mammals have proposed that translesion synthesis by alternative polymerases function to replicate across an incised oligo-cross-link intermediate to provide a template for the second round of incisions $(20,68,69)$. Biochemically, Pol IV — the $\operatorname{din} B$ gene product — is capable of synthesizing through templates containing an unhooked oligo-bound cross-link in vitro, supporting the possibility that translesion synthesis could carry out this hypothetical step (49). In mammals, several polymerases have been speculated to participate in cross-link repair based on mutant hypersensitivity to chemicals that form cross-links in addition to in vitro evidence for the ability of certain polymerases to synthesize past partially incised cross-links (69-73). However, the potential role for translesion polymerases during cross-link repair in vivo has not been examined in bacteria. To this end, the comparative survival of a mutant lacking all three translesion polymerases-Pol II, Pol IV, and Pol V—was examined following UVA irradiation the presence of angelicin or 8-methoxypsoralen. Relative to wild type cells, the absence of translesion polymerases rendered cells modestly sensitive to monoadducts formed by angelicin (Figure 2.3A). Comparatively, in the presence of both monoadducts and DNA interstrand cross-links, the sensitivity remained nearly identical (Figure 2.3B). The observation that the presence of DNA interstrand cross-links does not further sensitize the polymerase mutants beyond that seen in the presence of monoadducts alone implies that the translesion polymerases are not contributing to the survival of interstrand cross-links in vivo. 

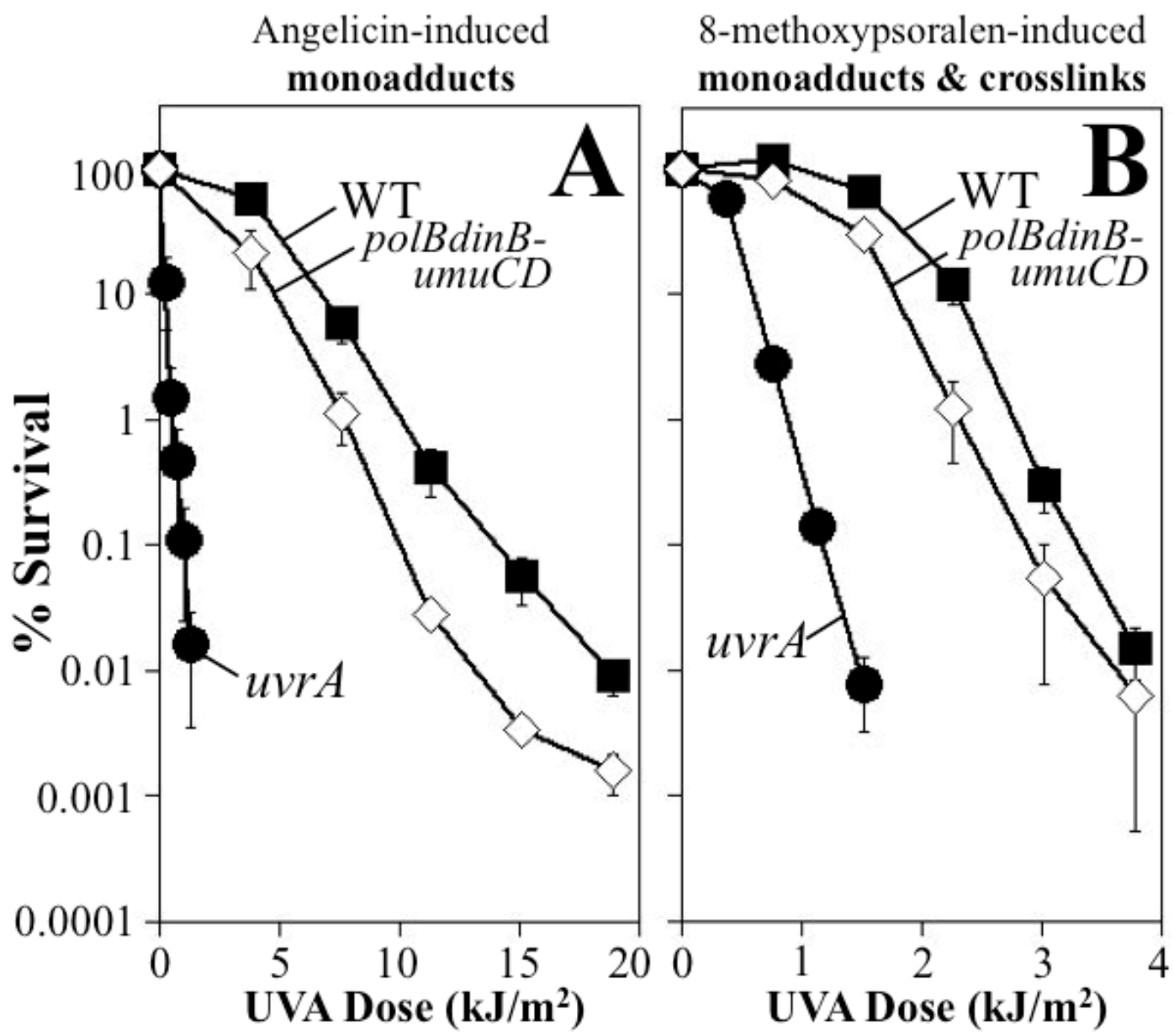

Figure 2.3. The transleison DNA polymerases do not contribute to survival in the presence of 8-methoxypsoralen-induced DNA interstrand cross-links. The survival of WT (filled squares), $u v r A$ (filled circles), and $\mathrm{polB} \operatorname{din} B$ umuDC (open diamonds) mutants following UVA irradiation in the presence of A) $40 \mu \mathrm{g} / \mathrm{mL}$ angelicin or B) $10 \mu \mathrm{g} / \mathrm{mL} \mathrm{8-}$ methoxypsoralen is plotted. Plots represent the average of at least 3 experiments. Error bars represent standard error of the mean. WT and $u v r A$ from Figure 2.1 shown for comparison.

\section{Double-strand breaks are not a prominent intermediate in the repair of DNA}

\section{interstrand cross-links}

Several models for interstrand cross-link repair propose that repair proceeds

through a double-strand break intermediate and requires recombination for repair to occur (50, 52-54, 74-78). Several genes in E. coli, when mutated, render cells hypersensitive to 
double-strand breaks. However, most of these mutants, including $\operatorname{rec} A$, are hypersensitive to multiple forms of DNA damage. $r e c N$-mutants are unique in that they are hypersensitive to agents that generate double-strand breaks such as gamma irradiation, mitomycin $\mathrm{C}$, nalidixic acid, or enzymatic restriction but are resistant to other forms of DNA damage that only induce single-strand lesions or monoadducts such as UV (79). Consistent with this role in repairing double-strand breaks, purified $\mathrm{RecN}$ binds and protects double-strand DNA ends and interacts with RecA to stimulate its ATPase activity and facilitate its loading at these damaged sites (80-82). If double-strand break intermediates form during the processing of interstrand-cross links, then one would expect recN mutants to be sensitive to 8-methoxypsoralen but not to angelicin. To examine this directly, we compared the survival of $\operatorname{rec} N$ mutants after UVA irradiation in the presence of angelicin and 8-methoxypsoralen. As shown in Figure 2.4A, recN mutants were modestly sensitive to monoadducts formed in the presence of angelicin and UVA light when compared to wild type cultures. Cells lacking RecN were also modestly sensitive to 8-methoxyporalen treatment, however the degree of sensitivity of this strain relative to wild type cells was similar irrespective of the chemical agent used (Figure 2.4B). The similar sensitivity of $r e c N$ mutants and wild type cells in the presence of monoadducts alone or both monoadducts and cross-links suggests that recN is not contributing to survival in the presence of interstrand cross-links. By comparison, rec $A$ mutants were hypersensitive to treatments that produced cross-links and monoadducts as well as monoadducts alone (Figure 2.4). 

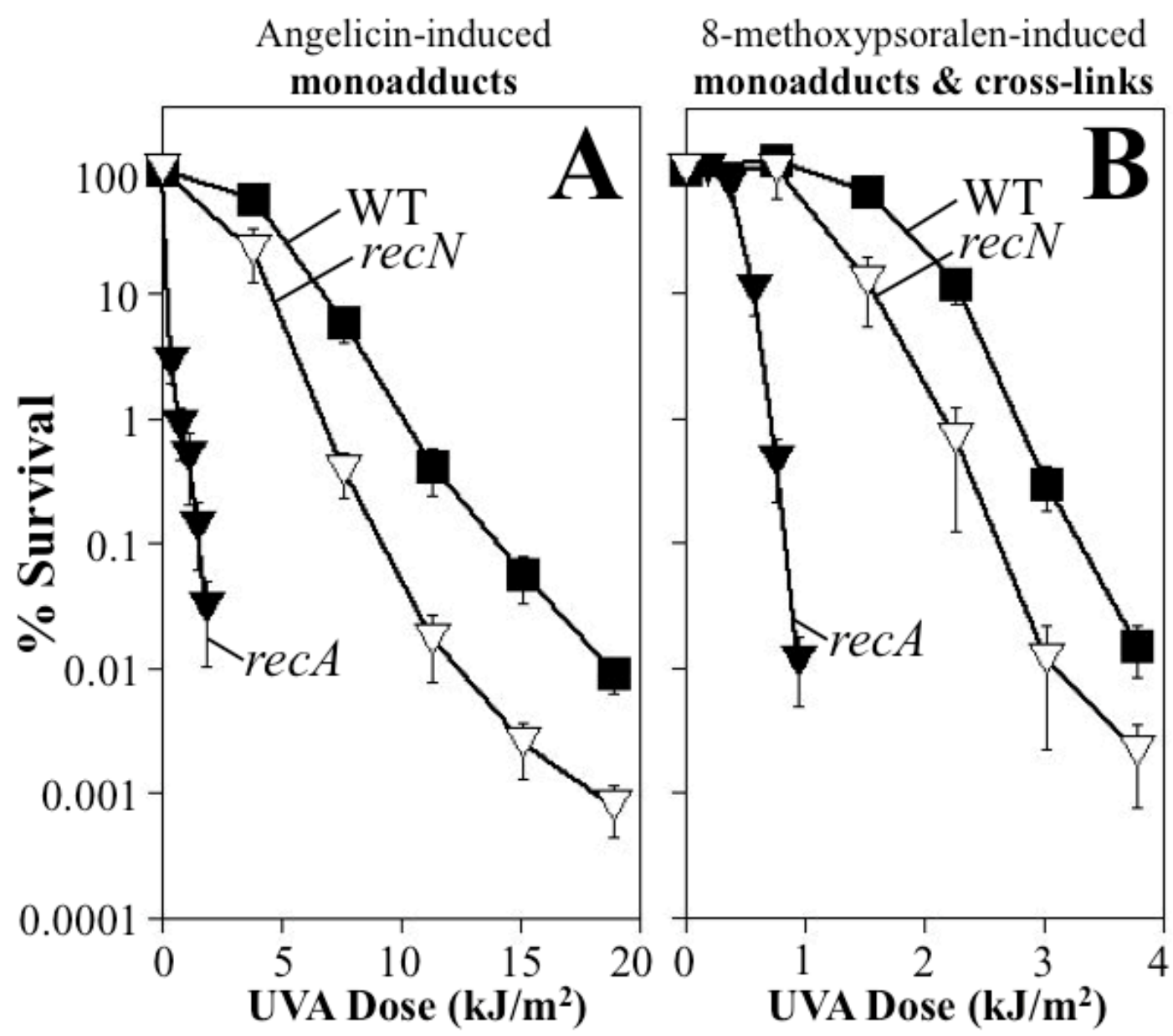

Figure 2.4 RecN, which is required for resistance to double-strand breaks, does not contribute to survival in the presence of DNA interstrand cross-links. The survival of WT (filled squares), $r e c A$ (filled triangles), and $\operatorname{rec} N$ (open triangles) mutants following UVA irradiation in the presence of A) $40 \mu \mathrm{g} / \mathrm{mL}$ angelicin or B) $10 \mu \mathrm{g} / \mathrm{mL}$ 8-methoxypsoralen is plotted. Plots represent the average of at least 3 experiments. Error bars represent standard error of the mean. WT from Figure 2.1 shown for comparison.

\section{Repair of interstrand cross-links is inefficient in $E$. coli}

The data presented in Figures 2.1-2.4 suggest that incisions by nucleotide excision repair, processing by double-strand break repair, or synthesis by translesion polymerases does not necessarily contribute to the survival of $E$. coli in the presence of interstrand cross-links. The survival results coupled with what we observed in the cross-link incision rate assay, prompted us to quantify the number of cross-links formed in vivo under the 
conditions used in our survival analysis. To accomplish this, we examined cross-link formation as a function of UVA dose on pBR322, an endogenous plasmid in $u v r A$ deficient cultures. Since $u v r A$ mutants fail to incise cross-links efficiently (Figure 2.2), these lesions accumulate and persist on the plasmid and therefore can be directly quantified. To this end, cultures containing plasmid pBR322 were grown in media containing $10 \mu \mathrm{g} / \mathrm{mL}$ 8-methoxypsoralen and irradiated with increasing UVA doses. Total genomic and plasmid DNA was then purified and digested with HindIII to linearize the plasmid. The samples were electrophoresed in an alkaline denaturing agarose gel and Southern analysis was used to identify and quantify the cross-links formed at each UVA dose $(41,83)$. As shown in Figure 2.5A, cross-linked structures appear as the higher migrating species in the Southern blot relative to the single-stranded linear DNA band. The percent of cross-linked DNA at each UVA dose was calculated by dividing the area of cross-linked plasmid DNA over total DNA per lane and then subtracting the same ratio of the untreated lane. Then, the inverse of each data point was plotted as percent crosslink-free plasmid as a function of UVA dose (Figure 2.5B) and the best-fit line was calculated under the assumption that DNA interstrand cross-links require absorption of two photons and, as demonstrated by a number of studies, form with second-order kinetics as a function of UVA dose $(12,23,40)$. 


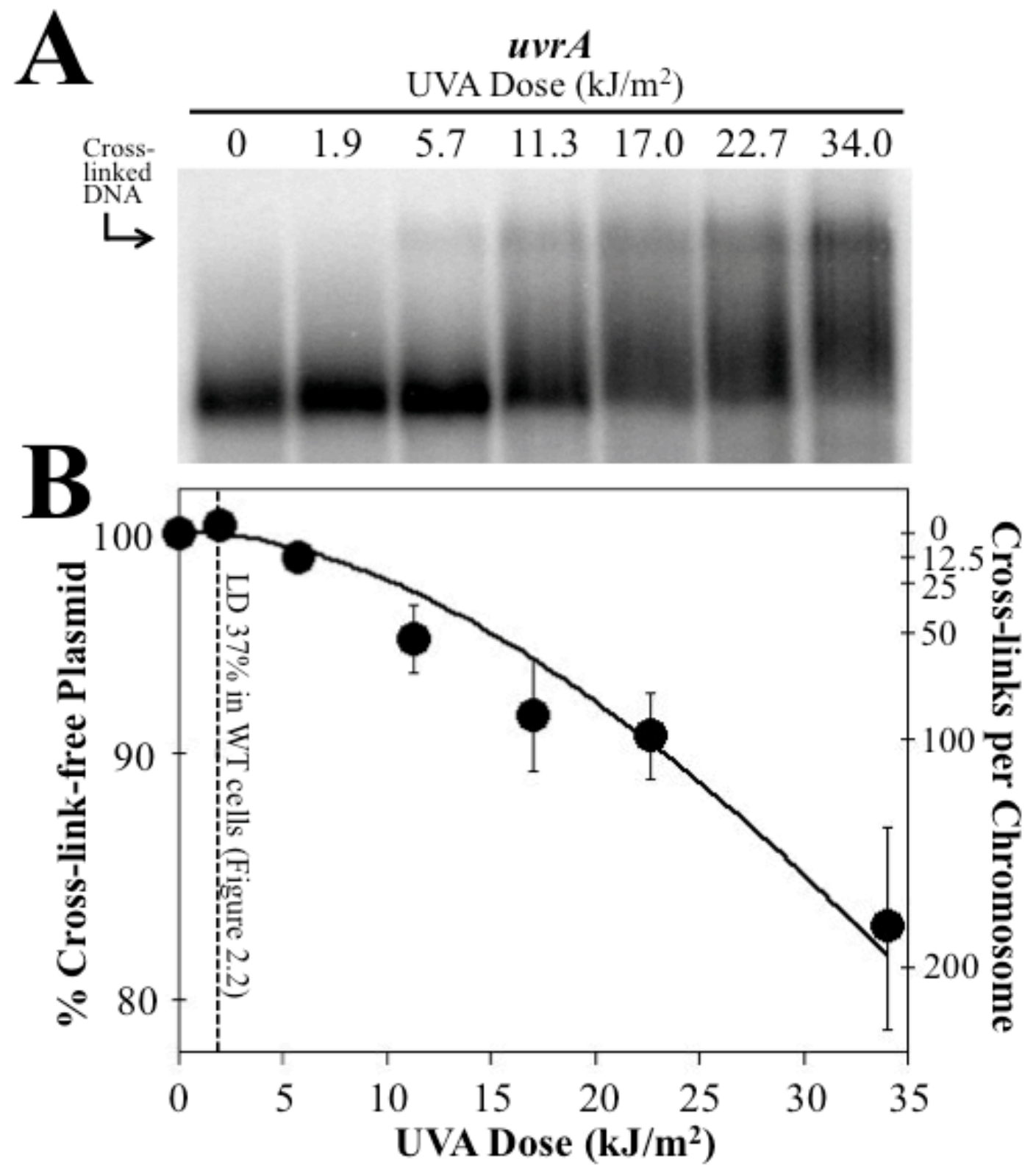

Figure 2.5. One cross-link is sufficient to inactivate our parental strain of E. coli. A) Dose response of interstrand cross-link formation in vivo. uvrA mutants containing plasmid pBR322 were UVA-irradiated at the indicated dose in the presence of $10 \mu \mathrm{g} / \mathrm{mL}$ of 8-methoxypsoralen. DNA from cultures were the immediately purified and analyzed as in Figure 2.2 to observe the instrand cross-links formed at each dose. B) The percent of cross-link-free $4.3-\mathrm{kb}$ plasmids remaining at each dose is plotted. The corresponding number of cross-links this represents per 4.6-Mb genome is also shown. Plots represent the average of 3 experiments. Error bars represent standard error of the mean. The best-fit line was calculated from the Poisson expression based on the assumption that absorption of 2-photon event is required to form an interstrand cross-link(40) (23) (63). The fraction of cross-link-free plasmids decreased at a rate of where $y=P_{(0)}+P_{(1)}=e^{-(m) x}+(m) x e^{-(m) x}$. 
Using this technique we are reasonably able to quantify cross-links when $\sim 1 \%$ of the plasmids have at least one cross-link. Per the best-fit line in Figure 2.5B, this 1\% detection limit corresponds to a minimum UVA dose of $\sim 6.5 \mathrm{~kJ} / \mathrm{m}^{2}$. Since we knew the size of plasmid pBR322 - 4,361 bp — and the percent of the plasmid population that had at least one cross-link, we were able to measure the number of cross-links induced at each UVA dose. We then applied this calculation to the E. coli genome- $\sim 4.6 \mathrm{Mb}-$ to estimate how many cross-links we were inducing per genome. A UVA dose of $6.5 \mathrm{~kJ} / \mathrm{m}^{2}$ corresponds to roughly 11 cross-links per/genome, however, this dose well exceeds the lethal dose in wild type cultures. Based on our analysis of wild type cultures, $\sim 1.8 \mathrm{~kJ} / \mathrm{m}^{2}$ UVA irradiation was required to reduce survival to $37 \%$ (Figure $2.1 \mathrm{~B}$ ). This is the UVA dose at which cells in the culture, on average, incur one lethal lesion. Since this dose was below the limit of detection, we estimated the number of cross-links/genome based on an extrapolation of our dose response curve and found that this UVA dose corresponds to $\sim 1$ cross-link in wild type cells. By this estimate, cells would lack or have an extremely inefficient system for repairing this form of damage. In $u v r A$ mutants, lethality occurred at $\sim 0.4 \mathrm{~kJ} / \mathrm{m}^{2}$, which corresponds with approximately 0.04 cross-links per genome. This likely argues that $u v r A$ mutants are killed by monoadducts before a cross-link is ever encountered in these cells. We infer from these results that E. coli may lack an effective, error-free mechanism for repairing interstrand cross-links.

\section{Discussion}

We show that although $u v r D$ mutants are hypersensitive to monoadducts, they are nearly as resistant as wild type cells in the presence of cross-links. The resistance of $u v r D$ 
mutants occurs despite their impaired ability to incise these lesions, similar to $u v r A$ mutants. In vitro, it is well established that proteins from the nucleotide excision repair pathway are able to recognize and incise psoralen cross-links (18) and that mutants lacking these enzymes fail to incise cross-links and are hypersensitive to psoralen in vivo $(18,23,24,37,38,40,41)$. This has led to the proposal in most current models that nucleotide excision repair initiates the removal of these lesion. However, nucleotide excision repair mutants are also hypersensitive to the presence of monoadducts. Psoralen, as with all cross-linking agents, induces monoadducts as well as cross-links which hampers the ability to determine whether nucleotide excision repair mutants are specifically sensitive to cross-links. The ratio of cross-links to monoadducts at a given UVA dose and 8-methoxypsoralen concentration varies depending on the cell line and further complicates in vivo studies using angelicin as a comparator (84-86). In the present study, we observed that the near wild type resistance of $u v r D$ mutants occurs despite an inability to make incisions, demonstrating the UvrD does not contribute to the repair process and that incisions by nucleotide excision repair enzymes are not essential for resistance to psoralen-induced cross-links. These results imply that the incisions by nucleotide excision repair are not contributing to survival in the presence of interstrand cross-links.

We also tested other aspects of cross-link repair models including the presence of a double-strand break intermediate and the participation of translesion DNA polymerases. In both cases, we observed that mutants impaired for double-strand break repair or lacking the translesion DNA polymerases did not exhibit any specific hypersensitivity to cross-links beyond that observed when exposed to monoadducts alone. Furthermore, the 
hypersensitivity of these mutants was relatively modest when either monoadducts alone or monoadducts and cross-links were present. Taken together, this results of this comparative analysis would argue that many of the proteins and pathways frequently proposed to participate in the repair process including nucleotide excision repair, doublestrand break repair, or translesion synthesis do not improve cell survival in the presence of these lesions.

The lack of contribution by these pathways led us to examine the cell's overall repair capacity for interstrand cross-links. Our estimates, based on the differential mobility of cross-linked fragments in alkali agarose gels, suggests that doses which generate only 1 cross-link per genome are sufficient to inactivate our wild type strain. If these estimates are accurate, this would be consistent with our observations that neither nucleotide excision repair, double-strand break repair, nor translesion synthesis contributes to survival. Further, this would argue that $E$. coli lacks an efficient or effective mechanism for repairing this form of damage.

Early studies in the repair of cross-links in $E$. coli began with the assumption that an effective repair pathway is likely to exist $(11,12,14,22,23,38-40,56,57,87,88)$. This assumption has persisted in more recent work, including from our lab (41). Several of these studies have characterized the survival and recovery of cultures that were treated with psoralen plus UVA and some reported that repair mutants, such as $r e c A$ and $u v r A$, were hypersensitive to psoralen and that incision intermediates appeared over time but were only re-joined in wild type cells. Although these observations were attributed to the formation and removal of interstrand cross-links, it seems likely that most of these phenotypes could also be attributed to a compromised ability to process monoadducts, 
which are generated at higher frequencies and require these enzymes for repair. These studies were generally unable to differentiate between the cellular effects cause by monoadducts or cross-links, and this issue remains a challenge in present studies.

Angelicin and psoralen have previously been used in a comparative manner to study interstrand cross-link repair or recovery, as we have here, but these analyses were limited to comparing the overall toxicity and mutagenicity of monoadducts to cross-links $(14,56,57)(89)$. Interestingly, in all cases, there was consensus that lethality was almost entirely attributed to the presence of cross-links, consistent with the general idea that the repair capacity of these lesions is limited. In one of the few studies that measured crosslinks directly, Lin et al. observed that the surviving fraction of psoralen plus UVA treated phage was always equivalent to the fraction of phage that remained cross-link free, consistent with the idea that cross-links cannot successfully be repaired (23).

Finally, based on our ability to detect cross-links using alkali agarose gels and Southern analysis, we estimated that only 1 lesion was sufficient to inactivate our wild type cells. Our limit of detection for cross-links in our assay was $\sim 11$ cross-links per chromosome and occurred at a dose well beyond the lethal dose for our wild type culture. Thus, if our method of quantifying cross-links is accurate, the ability of E. coli to repair these lesions is extremely limited. The only other estimate of cross-link repair capacity in E. coli comes from an early study by Cole (38) who reported that the AB1157 strain was capable of surviving treatments generating 67 cross-links. Cole stated that these estimates were derived from the elution pattern of single- and double-strand DNA from hydroxyapatite columns, but the data and methodology were not shown. Additionally, Cole inferred that cross-links formed at similar rates in UVA-irradiated cells as when 
DNA was purified in solution and that cross-link formation increased linearly with UVA dose $(90)(38,91)$. Neither of these assumptions turned out to be correct and both would significantly over-estimate the number of cross-links at low UVA doses (92). Subsequent work from the group of Howard-Flanders questioned the accuracy of the hydroxyapatite method and used alkali sucrose gradient sedimentation to demonstrate that psoralen cross-links form with second-order kinetics, consistent with their required absorption of two photons (40) (23). Although the Howard-Flanders studies quantified psoraleninduced cross-links and demonstrated a single cross-link was sufficient to inactivate phage lambda, they did not determine the lethal number of cross-links for the bacteria. A limitation in all previous studies, as well as the study presented here, is that current methods depend on extrapolation to determine the repair capacity of cells in culture since lethality occurs at doses below the limit of detecting these lesions directly. While the precise number of cross-links that can be repaired varies modestly between methods of estimation, it is clear that the repair capacity for these lesions is very limited. The limited capacity for wild type cells to repair and survive cross-links suggests 8-methoxysporalen plus UVA may be more comparable to treatments such as nalidixic acid or rifampicin. Unlike irradiation with UVC, when these drugs effectively target their respective essential cellular functions, cells lack true repair pathways for clearing this form of damage. Earlier work noted that while highly lethal overall, cells surviving cross-links contain high frequencies of deletions and point mutations that only appeared in nucleotide excision-proficient strains (40) (93), consistent with the idea that a significant portion of these repair attempts are not accurate. In mammalian cells, double-strand breaks are proposed to form predominantly following treatment with cross-linking agents 
(75) (77) (78). It may be the case that the presence of double-strand end-joining activity and large proportion of noncoding DNA allow mammalian cells to survive inaccurate or deletion-prone repair events better than $E$. coli. This will be an addressable and important question to focus on in our future work.

\section{References}

1. Brookes P, Lawley PD (1960) The reaction of mustard gas with nucleic acids in vitro and in vivo. Biochem J 77(3):478-484.

2. Brookes P, Lawley PD (1961) The reaction of mono- and di-functional alkylating agents with nucleic acids. Biochem J 80(3):496-503.

3. Iyer VN, Szybalski W (1963) A molecular mechanism of mitomycin action: Linking of complementary DNA strands. Proc Natl Acad Sci U S A 50:355-362.

4. Dall'Acqua F, Marciani S, Ciavatta L, Rodighiero G (1971) Formation of interstrand cross-linkings in the photoreactions between furocoumarins and DNA. $Z$ Naturforsch B 26(6):561-569.

5. Dijt FJ, Fichtinger-Schepman AM, Berends F, Reedijk J (1988) Formation and repair of cisplatin-induced adducts to DNA in cultured normal and repair-deficient human fibroblasts. Cancer Res 48(21):6058-6062.

6. Lawley PD, Brookes P (1968) Cytotoxicity of alkylating agents towards sensitive and resistant strains of Escherichia coli in relation to extent and mode of alkylation of cellular macromolecules and repair of alkylation lesions in deoxyribonucleic acids. Biochem J 109(3):433-447.

7. Pathak MA, Fellman JH, Kaufman KD (1960) The Effect of Structural Alterations on the Erythemal Activity of Furocoumarins: Psoralens** From the Departments of Dermatology and Biochemistry, University .... Journal of Investigative ...

8. Honig B, Morison WL, Karp D (1994) Photochemotherapy beyond psoriasis. J Am Acad Dermatol 31(5 Pt 1):775-790.

9. Chakraborty DP, Roy S, Chakraborty AK (1996) Vitiligo, psoralen, and melanogenesis: some observations and understanding. Pigment Cell Res 9(3):107116.

10. Huang Y, Li L (2013) DNA crosslinking damage and cancer - a tale of friend and foe. Transl Cancer Res 2(3):144-154.

11. Cole RS (1973) Repair of DNA containing interstrand crosslinks in Escherichia coli: sequential excision and recombination. Proc Natl Acad Sci U S A 70(4):10641068.

12. Sinden RR, Cole RS (1978) Repair of cross-linked DNA and survival of Escherichia coli treated with psoralen and light: effects of mutations influencing genetic recombination and DNA metabolism. J Bacteriol 136(2):538-547.

13. Magaña-Schwencke N, Henriques JA, Chanet R, Moustacchi E (1982) The fate of 
8-methoxypsoralen photoinduced crosslinks in nuclear and mitochondrial yeast DNA: comparison of wild-type and repair-deficient strains. Proc Natl Acad Sci US A 79(6):1722-1726.

14. Seki T, Nozu K, Kondo S (1978) Differential causes of mutation and killing in Escherichia coli after psoralen plus light treatment: monoadducts and cross-links. Photochem Photobiol 27(1):19-24.

15. Tessman JW, Isaacs ST, Hearst JE (1985) Photochemistry of the furan-side 8methoxypsoralen-thymidine monoadduct inside the DNA helix. Conversion to diadduct and to pyrone-side monoadduct. Biochemistry 24(7):1669-1676.

16. Dusre L, Covey JM, Collins C, Sinha BK (1989) DNA damage, cytotoxicity and free radical formation by mitomycin $\mathrm{C}$ in human cells. Chem Biol Interact 71(1):63-78.

17. Yin L, Chun EH, Rutman RJ (1973) A comparison of the effects of alkylation on the DNA of sensitive and resistant lettre-Ehrlich cells following in vivo exposure to nitrogen mustard. Biochim Biophys Acta 324(4):472-481.

18. Van Houten B, Gamper H, Holbrook SR, Hearst JE, Sancar A (1986) Action mechanism of ABC excision nuclease on a DNA substrate containing a psoralen crosslink at a defined position. Proc Natl Acad Sci U S A 83(21):8077-8081.

19. Berardini M, Mackay W, Loechler EL (1997) Evidence for a recombinationindependent pathway for the repair of DNA interstrand cross-links based on a sitespecific study with nitrogen mustard. Biochemistry 36(12):3506-3513.

20. Couvé S, Macé-Aimé G, Rosselli F, Saparbaev MK (2009) The human oxidative DNA glycosylase NEIL1 excises psoralen-induced interstrand DNA cross-links in a three-stranded DNA structure. J Biol Chem 284(18):11963-11970.

21. Semlow DR, Zhang J, Budzowska M, Drohat AC, Walter JC (2016) ReplicationDependent Unhooking of DNA Interstrand Cross-Links by the NEIL3 Glycosylase. Cell 167(2):498-511.e14.

22. Cole RS, Sinden RR (1975) Repair of cross-linked DNA in Escherichia coli. Basic life sciences

23. Lin PF, Bardwell E, Howard-Flanders P (1977) Initiation of genetic exchanges in lambda phage--prophage crosses. Proc Natl Acad Sci U S A 74(1):291-295.

24. Sladek FM, Munn MM, Rupp WD, Howard-Flanders P (1989) In vitro repair of psoralen-DNA cross-links by RecA, UvrABC, and the 5'-exonuclease of DNA polymerase I. J Biol Chem 264(12):6755-6765.

25. Sancar A (1996) DNA excision repair. Annu Rev Biochem 65:43-81.

26. Sancar A, Tang MS (1993) Nucleotide excision repair. Photochem Photobiol 57(5):905-921.

27. Sancar A, Rupp WD (1983) A novel repair enzyme: UVRABC excision nuclease of Escherichia coli cuts a DNA strand on both sides of the damaged region. Cell 33(1):249-260.

28. Setlow RB, Carrier WL (1963) The disappearance of thymine dimers from DNA: an error-correcting mechanism. 1963. DNA Repair (Amst) 2(11):1274-1279.

29. Howard-Flanders P, Theriot L, Stedeford JB (1969) Some properties of excisiondefective recombination-deficient mutants of Escherichia coli K-12. J Bacteriol 97(3):1134-1141. 
30. Courcelle J, Crowley DJ, Hanawalt PC (1999) Recovery of DNA replication in UVirradiated Escherichia coli requires both excision repair and recF protein function. $J$ Bacteriol 181(3):916-922.

31. Courcelle J, Donaldson JR, Chow KH, Courcelle CT (2003) DNA damage-induced replication fork regression and processing in Escherichia coli. Science 299(5609):1064-1067.

32. Caron PR, Kushner SR, Grossman L (1985) Involvement of helicase II (uvrD gene product) and DNA polymerase I in excision mediated by the uvrABC protein complex. Proc Natl Acad Sci U S A 82(15):4925-4929.

33. Husain I, Van Houten B, Thomas DC, Abdel-Monem M, Sancar A (1985) Effect of DNA polymerase I and DNA helicase II on the turnover rate of UvrABC excision nuclease. Proc Natl Acad Sci U S A 82(20):6774-6778.

34. Orren DK, Selby CP, Hearst JE, Sancar A (1992) Post-incision steps of nucleotide excision repair in Escherichia coli. Disassembly of the UvrBC-DNA complex by helicase II and DNA polymerase I. J Biol Chem 267(2):780-788.

35. Kuemmerle NB, Masker WE (1980) Effect of the uvrD mutation on excision repair. $J$ Bacteriol 142(2):535-546.

36. van Sluis CA, Moolenaar GF, Backendorf C (1983) Regulation of the uvrC gene of Escherichia coli K12: localization and characterization of a damage-inducible promoter. EMBO J 2(12):2313-2318.

37. Cole RS (1971) Properties of F' factor deoxyribonucleic acid transferred from ultraviolet-irradiated donors: photoreactivation in the recipient and the influence of recA, recB, recC, and uvr genes. J Bacteriol 106(1):143-149.

38. Cole RS (1971) Inactivation of Escherichia coli, F' episomes at transfer, and bacteriophage lambda by psoralen plus 360-nm light: significance of deoxyribonucleic acid cross-links. J Bacteriol 107(3):846-852.

39. Cole RS, Levitan D, Sinden RR (1976) Removal of psoralen interstrand cross-links from DNA of Escherichia coli: mechanism and genetic control. $J$ Mol Biol 103(1):39-59.

40. Cassuto E, Gross N, Bardwell E, Howard-Flanders P (1977) Genetic effects of photoadducts and photocross-links in the DNA of phage lambda exposed to $360 \mathrm{~nm}$ light and tri-methylpsoralen or khellin. Biochim Biophys Acta 475(4):589-600.

41. Perera AV, Mendenhall JB, Courcelle CT, Courcelle J (2016) Cho Endonuclease Functions during DNA Interstrand Cross-Link Repair in Escherichia coli. $J$ Bacteriol 198(22):3099-3108.

42. Moolenaar GF, van Rossum-Fikkert S, van Kesteren M, Goosen N (2002) Cho, a second endonuclease involved in Escherichia coli nucleotide excision repair. Proc Natl Acad Sci U S A 99(3):1467-1472.

43. Dye K, Ahmad SI (1995) Repair of phage lambda DNA damaged by near ultraviolet light plus 8-methoxypsoralen. J Gen Virol 76 (Pt 3):723-726.

44. Berardini M, Foster PL, Loechler EL (1999) DNA polymerase II (polB) is involved in a new DNA repair pathway for DNA interstrand cross-links in Escherichia coli. $J$ Bacteriol 181(9):2878-2882.

45. Escarceller M et al. (1994) Involvement of Escherichia coli DNA polymerase II in response to oxidative damage and adaptive mutation. J Bacteriol 176(20):6221- 
6228.

46. Rangarajan S, Woodgate R, Goodman MF (1999) A phenotype for enigmatic DNA polymerase II: a pivotal role for pol II in replication restart in UV-irradiated Escherichia coli. Proc Natl Acad Sci U S A 96(16):9224-9229.

47. Kow YW et al. (1993) Absence of a role for DNA polymerase II in SOS-induced translesion bypass of phi X174. J Bacteriol 175(2):561-564.

48. Courcelle CT, Belle JJ, Courcelle J (2005) Nucleotide excision repair or polymerase $\mathrm{V}$-mediated lesion bypass can act to restore UV-arrested replication forks in Escherichia coli. J Bacteriol 187(20):6953-6961.

49. Kumari A et al. (2008) Replication bypass of interstrand cross-link intermediates by Escherichia coli DNA polymerase IV. J Biol Chem 283(41):27433-27437.

50. De Silva IU, McHugh PJ, Clingen PH, Hartley JA (2000) Defining the roles of nucleotide excision repair and recombination in the repair of DNA interstrand cross-links in mammalian cells. Mol Cell Biol 20(21):7980-7990.

51. Bessho T, Mu D, Sancar A (1997) Initiation of DNA interstrand cross-link repair in humans: the nucleotide excision repair system makes dual incisions 5 'to the crosslinked base and removes a 22-to 28- .... Molecular and Cellular Biology

52. Niedernhofer LJ et al. (2004) The structure-specific endonuclease Ercc1-Xpf is required to resolve DNA interstrand cross-link-induced double-strand breaks. $\mathrm{Mol}$ Cell Biol 24(13):5776-5787.

53. Sczepanski JT, Jacobs AC, Van Houten B, Greenberg MM (2009) Double-strand break formation during nucleotide excision repair of a DNA interstrand cross-link. Biochemistry 48(32):7565-7567.

54. Peng X, Ghosh AK, Van Houten B, Greenberg MM (2010) Nucleotide excision repair of a DNA interstrand cross-link produces single- and double-strand breaks. Biochemistry 49(1):11-19.

55. Kaye J, Smith CA, Hanawalt PC (1980) DNA repair in human cells containing photoadducts of 8-methoxypsoralen or angelicin. Cancer Res 40(3):696-702.

56. Bordin F, Carlassare F, Baccichetti F, Anselmo L (1976) DNA repair and recovery in Escherichia coli after psoralen and angelicin photosensitization. Biochim Biophys Acta 447(3):249-259.

57. Ashwood-Smith MJ, Grant E (1977) Conversion of psoralen DNA monoadducts in E. coli to interstrand DNA cross links by near UV light (320-360 nm): Inability of angelicin to form cross links, in vivo. Experientia 15;33(3):384-386.

58. Courcelle J, Carswell-Crumpton C, Hanawalt PC (1997) recF and recR are required for the resumption of replication at DNA replication forks in Escherichia coli. Proc Natl Acad Sci U S A 94(8):3714-3719.

59. Newton KN, Courcelle CT, Courcelle J (2012) UvrD Participation in Nucleotide Excision Repair Is Required for the Recovery of DNA Synthesis following UVInduced Damage in Escherichia coli. J Nucleic Acids 2012:271453.

60. Yu D et al. (2000) An efficient recombination system for chromosome engineering in Escherichia coli. Proc Natl Acad Sci U S A 97(11):5978-5983.

61. Murphy KC, Campellone KG, Poteete AR (2000) PCR-mediated gene replacement in Escherichia coli. Gene 246(1-2):321-330.

62. Davis BD (1949) The Isolation of Biochemically Deficient Mutants of Bacteria by 
Means of Penicillin. Proc Natl Acad Sci U S A 35(1):1-10.

63. Kanne D, Straub K, Rapoport H, Hearst JE (1982) Psoralen-deoxyribonucleic acid photoreaction. Characterization of the monoaddition products from 8methoxypsoralen and 4,5'8-trimethylpsoralen. Biochemistry 21(5):861-871.

64. Rodighiero G, Musajo L, Dall'Acqua... F (1970) Mechanism of skin photosensitization by forucoumarins: Photoreactivity of various furocoumarins with native DNA and with ribosomal RNA. ... et Biophysica Acta (BBA ...

65. Granger-Schnarr M, Daune MP, Fuchs RP (1986) Specificity of N-acetoxy-N-2acetylaminofluorene-induced frameshift mutation spectrum in mismatch repair deficient Escherichia coli strains mutH, L, S and U. J Mol Biol 190(3):499-507.

66. Washburn BK, Kushner SR (1991) Construction and analysis of deletions in the structural gene (uvrD) for DNA helicase II of Escherichia coli. J Bacteriol 173(8):2569-2575.

67. Crowley DJ, Hanawalt PC (2001) The SOS-dependent upregulation of uvrD is not required for efficient nucleotide excision repair of ultraviolet light induced DNA photoproducts in Escherichia coli. Mutat Res 485(4):319-329.

68. Lehoczký P, McHugh PJ, Chovanec M (2007) DNA interstrand cross-link repair in Saccharomyces cerevisiae. FEMS Microbiol Rev 31(2):109-133.

69. Ho TV, Schärer OD (2010) Translesion DNA synthesis polymerases in DNA interstrand crosslink repair. Environ Mol Mutagen 51(6):552-566.

70. Sarkar S, Davies AA, Ulrich HD, McHugh PJ (2006) DNA interstrand crosslink repair during G1 involves nucleotide excision repair and DNA polymerase zeta. EMBO J 25(6):1285-1294.

71. Mogi S, Butcher CE, Oh DH (2008) DNA polymerase eta reduces the gamma$\mathrm{H} 2 \mathrm{AX}$ response to psoralen interstrand crosslinks in human cells. Exp Cell Res 314(4):887-895.

72. Sharma S, Canman CE (2012) REV1 and DNA polymerase zeta in DNA interstrand crosslink repair. Environ Mol Mutagen 53(9):725-740.

73. Tomicic MT et al. (2014) Translesion polymerase $\eta$ is upregulated by cancer therapeutics and confers anticancer drug resistance. Cancer Res 74(19):5585-5596.

74. McHugh PJ, Sones WR, Hartley JA (2000) Repair of intermediate structures produced at DNA interstrand cross-links in Saccharomyces cerevisiae. Molecular and cellular ... 20(1):3425-3433.

75. Bessho T (2003) Induction of DNA replication-mediated double strand breaks by psoralen DNA interstrand cross-links. J Biol Chem 278(7):5250-5254.

76. Rothfuss A, Grompe M (2004) Repair Kinetics of Genomic Interstrand DNA CrossLinks: Evidence for DNA Double-Strand Break-Dependent Activation of the Fanconi Anemia/BRCA Pathway. Molecular and Cellular Biology 24(1):123-134.

77. Mogi S, Oh DH (2006) gamma-H2AX formation in response to interstrand crosslinks requires XPF in human cells. DNA Repair (Amst) 5(6):731-740.

78. Vare D et al. (2012) DNA interstrand crosslinks induce a potent replication block followed by formation and repair of double strand breaks in intact mammalian cells. DNA Repair (Amst) 11(12):976-985.

79. Picksley SM, Attfield PV, Lloyd RG (1984) Repair of DNA double-strand breaks in Escherichia coli K12 requires a functional recN product. Mol Gen Genet 195(1- 
2):267-274.

80. Grove JI, Wood SR, Briggs GS, Oldham NJ, Lloyd RG (2009) A soluble RecN homologue provides means for biochemical and genetic analysis of DNA doublestrand break repair in Escherichia coli. DNA Repair (Amst) 8(12):1434-1443.

81. Keyamura K, Sakaguchi C, Kubota Y, Niki H, Hishida T (2013) RecA protein recruits structural maintenance of chromosomes (SMC)-like RecN protein to DNA double-strand breaks. J Biol Chem 288(41):29229-29237.

82. Uranga LA, Reyes ED, Patidar PL, Redman LN, Lusetti SL (2017) The cohesinlike RecN protein stimulates RecA-mediated recombinational repair of DNA double-strand breaks. Nat Commun 8:15282.

83. Islas AL, Vos JM, Hanawalt PC (1991) Differential introduction and repair of psoralen photoadducts to DNA in specific human genes. Cancer Res 51(11):28672873.

84. Cao H, Hearst JE, Corash L, Wang Y (2008) LC-MS/MS for the detection of DNA interstrand cross-links formed by 8-methoxypsoralen and UVA irradiation in human cells. Anal Chem 80(8):2932-2938.

85. Lai C et al. (2008) Quantitative analysis of DNA interstrand cross-links and monoadducts formed in human cells induced by psoralens and UVA irradiation. Anal Chem 80(22):8790-8798.

86. Liu S, Wang Y (2013) A quantitative mass spectrometry-based approach for assessing the repair of 8-methoxypsoralen-induced DNA interstrand cross-links and monoadducts in mammalian cells. Anal Chem 85(14):6732-6739.

87. Cole RS (1973) Repair of interstrand cross-links in DNA induced by psoralen plus light. Yale J Biol Med 46(5):492.

88. Grover NB, Margalit A, Zaritsky A, Ben-Hur E, Hansen MT (1981) Sensitivity of exponentially growing populations of Escherichia coli to photo-induced psoralenDNA interstrand crosslinks. Biophys J 33(1):93-106.

89. Venturini S et al. (1980) Comparative mutagenicity of linear and angular furocoumarins in Escherichia coli strains deficient in known repair functions. Chem Biol Interact 30(2):203-207.

90. Cole RS (1970) Light-induced cross-linking of DNA in the presence of a furocoumarin (psoralen). Studies with phage lambda, Escherichia coli, and mouse leukemia cells. Biochim Biophys Acta 217(1):30-39.

91. Cole RS (1971) Psoralen monoadducts and interstrand cross-links in DNA. Biochimica et Biophysica Acta (BBA)-Nucleic Acids and ...

92. Bridges BA, Mottershead RP, Knowles A (1979) Mutation induction and killing of Escherichia coli by DNA adducts and crosslinks: a photobiological study with 8methoxypsoralen. Chem Biol Interact 27(2-3):221-233.

93. Sladek FM, Melian A, Howard-Flanders P (1989) Incision by UvrABC excinuclease is a step in the path to mutagenesis by psoralen crosslinks in Escherichia coli. Proc Natl Acad Sci U S A 86(11):3982-3986. 
Chapter III. Nth and Fpg Glycosylases, Xth and Nfo AP-Endonucleases sensitize Escherichia coli to psoralen-induced DNA damage

\begin{abstract}
In mammals, there are differing reports as to how base excision repair effects the removal and survival of cells in the presence of psoralen DNA interstrand cross-links. Bacterial base excision repair proteins are highly conserved with their eukaryotic counterparts, however, the functional role of base excision repair during cross-link repair in bacteria has not been thoroughly examined. To further characterize how this repair pathway contributes to interstrand cross-links repair, we compared the survival of UVA-irradiated mutants in the presence of 8-methoxypsoralen — which forms interstrand cross-links and monoadducts - to that of angelicin - a congener forming only monoadducts. We show that inactivating either Fapy or Endo III glycosylases, or Exo III or Endo IV AP endonucleases confers a modest resistance to psoralen adducts. With the exception of Endo IV, these enzymes sensitize cells to both angelicin and 8-methoxypsoralen. Further, we show that the absence of these enzymes did not detectably affect the rate that interstrand cross-links were incised or induced. However, their absence did reduce the rate that monoadducts appeared during UVA-irradiation. Taken together, the results are most consistent with the idea that the base excision repair enzymes sensitize cells to psoralen agents, by impeding the formation or repair of the monoadduct species. The glycosylases did not appear to contribute to survival, excision, or repair of the interstrand cross-links in vivo.
\end{abstract}




\section{Introduction}

DNA interstrand cross-links are a form of damage that covalently link complementary strands of DNA. Chemical agents that form cross-links are highly toxic and are widely used to treat cancer, vitiligo, and psoriasis (1) (2-4). Interstrand-crosslinks prevent the separation of the two DNA strands and therefore represent an absolute block to the essential processes of replication and transcription, and is thought to be the primary cause of lethality in cells $(5,6)$. Psoralens - tricyclic compounds comprised of furan and pyrone rings - intercalate DNA to form noncovalent bonds. At 5'-TA sequences, absorption of UVA light results in a covalent bond between the furan or pyrone ring and thymine. If the furan-side monoadduct absorbs a second photon, covalent linkage between the remaining pyrone ring can occur with a second pyrimidine, resulting in a DNA interstrand cross-link $(7,8)$. Thus, psoralen-induced damage creates both monoadducts and DNA interstrand cross-links. However, based on studies using compounds or conditions that preferentially generate a single form of damage, disruption of metabolic processes and lethality is thought to result almost entirely from the crosslink product $(6,9,10)$. The harmful nature of cross-link damage and the effective use of cross-linking agents in treating skin disease and some form of cancers has led to an interest in how these lesions are processed in cells.

The mechanism by which these lesions are repaired has been a challenge to address. In the case of monoadducts, the nucleotide excision repair pathway excises the damaged region of DNA and the complementary, undamaged strand can be used as a template to restore the excised region. Alternatively, in the case of the cross-links the adduct remains attached to the complementary strand following excision, preventing the 
completion of faithful repair. To address this, several models have been proposed for the repair of interstrand cross-links, each involving the combined action of several repair pathways acting sequentially. Most models propose that repair is initiated by nucleotide excision repair-catalyzed excision, and that either recombination or translesion synthesis then acts to restores the template of the incised region(11-14). In theory, a second round of nucleotide excision repair would then be able to complete the repair process. Other models suggest that incisions by nucleotide excision repair of both strands may lead to breaks that require double strand break repair pathways (15-17).

Despite these models, there is little evidence to support the idea that these pathways contribute to survival in the presence of interstrand cross-links exclusively. Nucleotide excision repair appears to recognize and incise cross-links both in vivo and in vitro $(13,18)$. However, in Chapter II of this manuscript we show that other nucleotide excision repair mutants, such as $u v r D$, fail to incise interstrand cross-links in vivo but remain nearly as resistant as wild type cells to interstrand cross-links. Similarly, mutants lacking translesion polymerases, or impaired for double strand break repair are no more hypersensitive to cross-linking agents than agents producing monoadducts alone, arguing that these pathways do not significantly contribute to survival in the presence of crosslinks. Furthermore, we also showed through direct calculations of a lethal dose of interstrand cross-links in $E$. coli that as few as 1 cross-link is sufficient to inactivate cells. Thus, it is possible that each of these pathways attempts to process these lesions but that their complexity prevents successful repair in cells and that multiple repair pathways cannot effectively operate sequentially as proposed in most models. While these observations may argue against an efficient mechanism for interstrand cross-link repair, 
in humans cancer cells are known to develop resistance to cross-link based chemotherapeutics (19-21). This suggests the possibility that the normal repair pathways that interact inadequately with cross-links can be altered to process these lesions and therefore characterization of the mechanisms involved in typical interactions with crosslinked DNA is of importance.

Base excision repair is one pathway that has recently garnered interest for its potential effects on cross-link repair. There are conflicting reports as to the overall role of base excision repair in cross-link survival, with studies mostly in vertebrates suggesting that it can either promote or hinder repair. Early studies proposed that a glycosylase acting to detach a cross-link from a substrate such as a stalled replication fork would represent a less dangerous lesion for the cell, as it would avoid an early break of the DNA backbone (22). In support of this, 3-methyladenine DNA glycosylase (Aag) was shown to protect against the clastogenic effects of MMC in murine embryonic stem cells, improving cell survival and decreasing sister chromatid exchanges(23). However, the same study found no effect when nitrogen mustard was used as a cross-linking agent, suggesting that the repair process was agent-specific. Couvé et al. showed that purified Endo-VIII-like protein, NEIL1, was capable of incising psoralen-induced monoadducts from oligonucleotide duplexes, but not cross-links (24), leading the authors to speculate that base excision repair proteins may act at a late step in the repair pathway. They later confirmed that NEIL1 could initiate repair of psoralen cross-links on substrates mimicking those encountered during the second round of incisions on synthetic substrates in vitro and that mutations in this gene product sensitized cells to psoralen (25). In nonsmall cell lung cancer cells, overexpression of APE1 - the human apurinic/apyrimidinic 
endonuclease - has been correlated cisplatin resistance, a cross-linking agent commonly used in chemotherapy (26). This would seem to imply that APE1 protects against lethality from cross-links.

Other studies suggest base excision repair impairs survival in the presence of cross-links. Loss of uracil DNA glycosylase (UNG) in primary mouse embryonic fibroblasts has been reported to confer cisplatin resistance (27). The authors demonstrated that, in vitro, cisplatin cross-links could lead to the preferential deamination of surrounding cytosines and that UNG may lead to detrimental breaks at these locations. McNeill et al. demonstrated that NEIL1 binds to trioxsalen cross-link substrates in vitro and that in LN428 cells NEIL1 slows recruitment of XPC, a protein required for global nucleotide excision repair (28). Finally, using Xenopus egg extracts, NEIL3 glycosylase has been found to be capable of incising psoralen but not cisplatin DNA cross-links on plasmids substrates (29). The authors propose that this may represent a mechanism that promotes repair of psoralen cross-links, however whether NEIL3 operates in this manner in vivo has not been examined. In vitro, several DNA glycosylases from both prokaryotes and eukaryotes have been shown to bind and/or incise both psoralen monoadducts and cross-links $(25)(28,30)(29)(31)$. However, it is not clear whether these gene products act explicitly on cross-links or monoadducts in vivo.

Identifying genes that specifically process or affect survival of interstrand crosslinks has remained a challenge because all cross-linking agents induce multiple forms of damage (32-34) and most mutants that have been identified as hypersensitive to crosslinking agents are also hypersensitive to chemicals producing monoadducts (9), making it difficult to attribute the mutant's hypersensitivity to the cross-link. Therefore, to 
differentiate and identify gene products that are specifically involved in processing crosslinks, monoadducts, cross-links, or both, we compared the survival of $E$. coli cultures irradiated with UVA in the presence of 8-methoxypsoralen or angelicin. The comparison between 8-methoxypsoralen and angelicin allowed us to differentiate between genes that are involved in the general repair of monoadducts from those that may have a specific role in interstrand cross-link repair (35). 8-methoxypsoralen forms DNA monoadducts and interstrand cross-links at different ratios depending on concentration of drug, dose of UVA light, and cell line (36) (37-39). Angelicin is a congener of psoralen whose angular structure renders its unable to form cross-links, producing almost entirely monoadducts $(11,40,41)(42)$. Thus, the survival of mutants lacking gene products specific to processing interstrand cross-links would be expected to be distinct between 8 methoxypsoralen and angelicin relative to wild type cultures. Here, we characterized several base excision repair mutants that have been proposed to be involved in psoralen cross-link processing based on previous biochemical studies in bacteria or their mammalian homologs.

\section{Methods}

Bacterial Strains. The parent strain used in this study is SR108, a thyA36 deoC2 derivative of W3110(43, 44). Isogenic strains lacking uvrA (HL952), nei (CL1005), nth (CL1006), fpg (CL1009), and fpg nth nei (CL1938) were constructed using standard P1 transduction methods and have been described previously $(45,46)$. Isogenic strains lacking $n f o$ (CL1116) and $n f i$ (CL1326) were made by standard P1 transduction of the 
nfo-1::kan marker from BW540 and nfi-1::cat marker from BW1171 into SR108, respectively (47) (48).

CL1155 (DY329 xth::cat) was constructed using the recombineering strain DY329 (49). The chloramphenicol resistance gene was amplified from TP507 (50) using PCR primers xthF-catF, 5'gtctcttttaatatcaacggectgegegccagacctcacTGTGACGGAAGATCACTTCG, and xthRcatR, 5'cggtttttccatgctgcggatttcatagtcgatgccggtACCAGCAATAGACATAAGCG. The PCR product was then transformed into DY329 to generate CL1155, selecting for chloramphenicol resistance. The gene replacement was transferred into SR108 using standard P1 transduction to generate the isogenic $x$ th strain used in this study, CL1168.

Psoralen-UVA and Angelicin-UVA Survival Assays. Fresh overnight cultures were diluted 1:100 in 8-mL Davis medium (51) supplemented with $0.4 \%$ glucose, $0.2 \%$ Casamino Acids, and $10 \mu \mathrm{g} / \mathrm{mL}$ thymine (DGCthy) and grown at $37^{\circ} \mathrm{C}$ to an optical density of 0.4 at $600 \mathrm{~nm}$ (OD600). At this time, $10 \mu \mathrm{g} / \mathrm{mL}$ of 8-methoxypsoralen or $40 \mu \mathrm{g} / \mathrm{mL}$ of angelicin was added to the cultures and incubation continued for $10 \mathrm{~min}$. Angelicin-treated cells were UVA-irradiated for longer time increments than 8-methoxypsoralen-treated cells in order to achieve comparable kill curves for wild type cells in either condition. Cells were then irradiated using two 32-watt UVA bulbs (Sylvania) with a peak emittance of $320 \mathrm{~nm}$ at an incident dose of $6.3 \mathrm{~J} / \mathrm{m} 2 / \mathrm{s}$. At the times indicated, $100-\mu \mathrm{L}$ aliquots were removed from each culture and serially diluted in 10 -fold increments. Triplicate $10-\mu 1$ aliquots of each dilution were spotted onto Luria-Bertani agar plates supplemented with $10 \mu \mathrm{g} / \mathrm{mL}$ thymine (LBthy) and incubated at $37^{\circ} \mathrm{C}$. Viable colonies were counted the next day to 
determine the surviving fraction. 8-methoxypsoralen was purchased from Acros Organics (item 298-81-7, lot A0143457). Angelicin was purchased from Sigma-Aldrich (item A0956, lot 042M4054V).

In vivo detection of DNA interstrand cross-links. Cultures containing the plasmid pBR322 were grown overnight at $37^{\circ} \mathrm{C}$ in DGCthy medium supplemented with $50 \mu \mathrm{g} / \mathrm{mL}$ of ampicillin. A $0.1-\mathrm{mL}$ aliquot from this culture was pelleted and resuspended in 10-mL DGCthy medium without ampicillin and grown in a $37^{\circ} \mathrm{C}$ shaking water bath to an OD600 of 0.4. At this time, cultures used for the incision/recovery assay were exposed to $20 \mu \mathrm{g} / \mathrm{mL} 8$-methoxypsoralen for $10 \mathrm{~min}$ at $37^{\circ} \mathrm{C}$ and subsequently irradiated with a UVA dose of $5.7 \mathrm{~kJ} / \mathrm{m}^{2}$. Irradiated cultures were then incubated for a recovery period of $120 \mathrm{~min}$ where $0.75-\mathrm{mL}$ aliquots were collected at times indicated and then transferred to an equal volume of ice-cold $2 X$ NET buffer (10mM Tris [pH 8.0], 40mM EDTA [pH 8.0], $400 \mathrm{mM} \mathrm{NaCl})$. Cells were pelleted, resuspended in $130-\mu \mathrm{L}$ lysis buffer $(1 \mathrm{mg} / \mathrm{ml}$ lysozyme, $0.5 \mathrm{mg} / \mathrm{mL}$ RNaseA in $10 \mathrm{mM}$ Tris, $1 \mathrm{mM}$ EDTA [pH 8.0]), and incubated at $37^{\circ} \mathrm{C}$ for $30 \mathrm{~min}$. Then, $10-\mathrm{uL}$ of $10 \mathrm{mg} / \mathrm{mL}$ proteinase $\mathrm{K}$ and $10-\mu \mathrm{L}$ of $20 \%$ Sarkosyl were added to the samples, and incubation continued for 1 hour at $37^{\circ} \mathrm{C}$. Samples were extracted with four volumes of phenol-chloroform, followed by two volumes of chloroform and then dialyzed against $200 \mathrm{ml}$ of $1 \mathrm{mM}$ Tris (pH 8.0), 1mM EDTA (pH 8.0) for $45 \mathrm{~min}$ using 47 -mm Millipore $0.025-\mu \mathrm{m}$ pore disks. The DNA was digested with HindIII (Thermo Fisher) overnight at $37^{\circ} \mathrm{C}$. Samples were electrophoresed on a $0.75 \%$ alkaline agarose gel in $30 \mathrm{mM} \mathrm{NaOH}, 1 \mathrm{mM}$ EDTA at $1 \mathrm{~V} / \mathrm{cm}$ for 16 hours. DNA in the gels was then transferred to Hybond $\mathrm{N}+$ nylon membranes (GE Healthcare) using 
standard Southern blotting techniques. The plasmid DNA was detected by probing with

${ }^{32} \mathrm{P}$-labeled pBR322 that was prepared by nick translation (Roche) using alpha ${ }^{32} \mathrm{P}-\mathrm{dCTP}$ $>6000 \mathrm{Ci} / \mathrm{mmol}$ (Perkin-Elmer). Southern blots were visualized using a Storm 840 phosphorimager (GE Biosciences) and its associated ImageQuant analysis software.

The fraction of 8-methoxypsoralen cross-links formed at each time point was calculated as the ratio of DNA running at about twice the molecular weight of the linear band to the total DNA per lane and normalized to the fraction of cross-links in untreated samples.

Fraction of cross-linked plasmid $=\left(\mathrm{XD}_{\text {time }(\mathrm{x})} / \mathrm{TD}_{\text {time }(\mathrm{x})}\right)-\left(\mathrm{XD}_{\text {untreated }} / \mathrm{TD}_{\text {untreated }}\right)$, where $\mathrm{XD}$ represents cross-linked DNA and TD represents total DNA.

\section{Results}

To examine how base excision repair affects survival in the presence of 8methoxypsoralen-induced DNA interstrand cross-links, we compared the survival of several glycosylase mutants following UVA irradiation in the presence of either 40 $\mu \mathrm{g} / \mathrm{mL}$ angelicin or $10 \mu \mathrm{g} / \mathrm{mL} 8$-methoxypsoralen. In previous work, these concentrations of have been shown to form adducts in DNA at similar frequencies for a given dose of UVA (40, 52). Angelicin plus $\sim 20 \mathrm{~kJ} / \mathrm{m}^{2}$ UVA irradiation reduced survival of wild type cells by more than four orders of magnitude (Figure 3.1A). By comparison, in the presence of 8-methoxypsoralen, a similar loss of viability was observed within $4 \mathrm{~kJ} / \mathrm{m}^{2}$, with lethality $\left(\mathrm{LD}_{37}\right)$ occurring at $\sim 1.8 \mathrm{~kJ} / \mathrm{m}^{2}$. In Chapter II, we show that this dose represents only about 1 cross-link per chromosome, consistent with cross-links being 
highly lethal lesions that lack an efficient mechanism of repair (53). In mutants lacking either Endo V (nfi) or Endo VIII (nei), we found that the survival was similar to that of wild type cells in the presence of either angelicin or 8-methoxypsoralen (Figure 3.1A\&B), arguing against a role for these enzymes in processing psoralen-induced damage. By comparison, in the absence of either Fapy (fpg) or Endo III (nth), cultures were modestly more resistant to UVA irradiation in the presence of either angelicin or 8methoxypsoralen compared to wild type cells (Figure 3.1). The resistance conferred by deletion of $f p g$ or $n t h$ in the presence of monoadducts was similar in magnitude to that seen with when both monoadducts and cross-links were present, arguing that these glycosylases are likely to sensitize cells to psoralen through interactions with the monoadducts, rather than cross-links. 

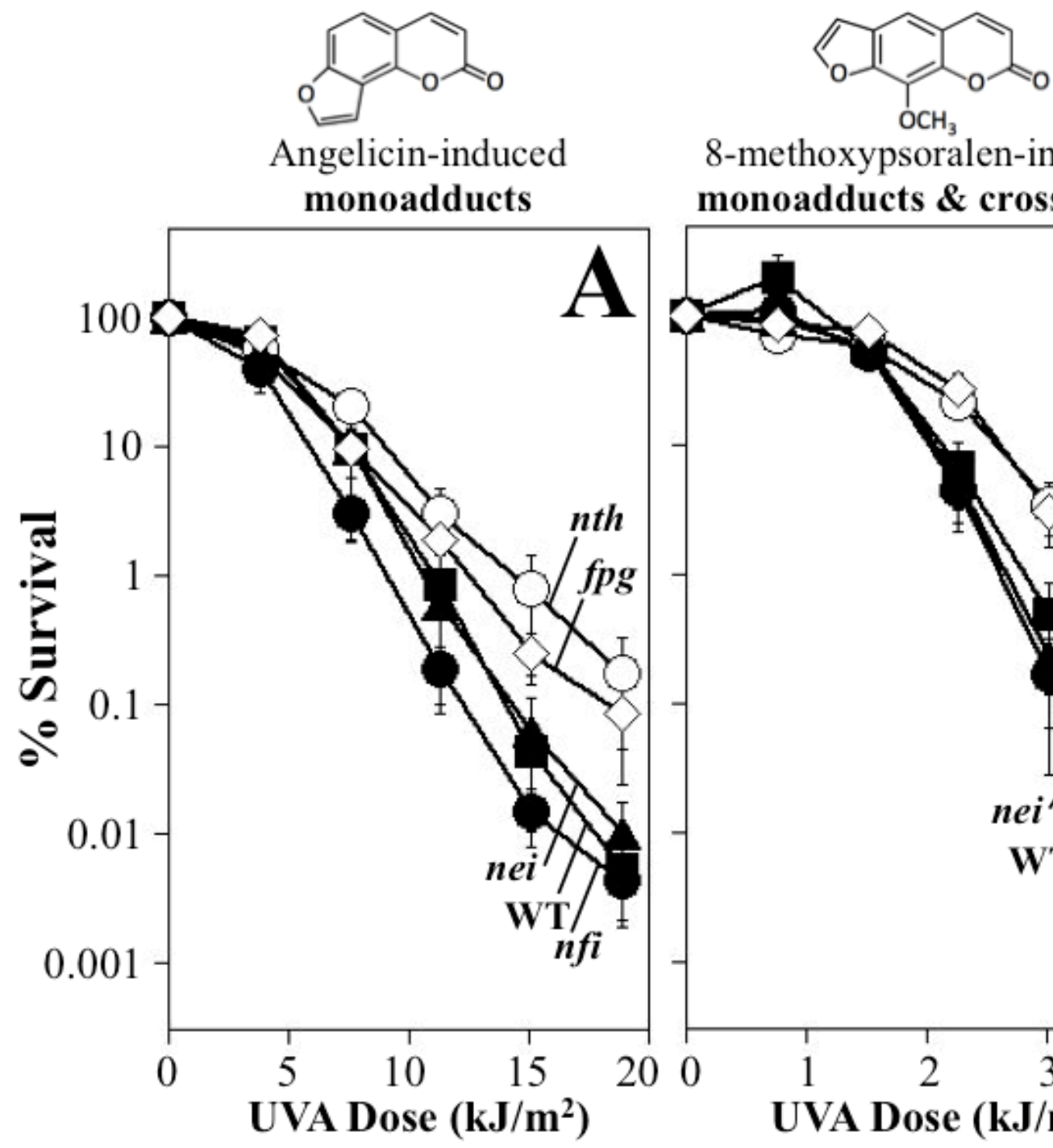

8-methoxypsoralen-induced monoadducts \& cross-links

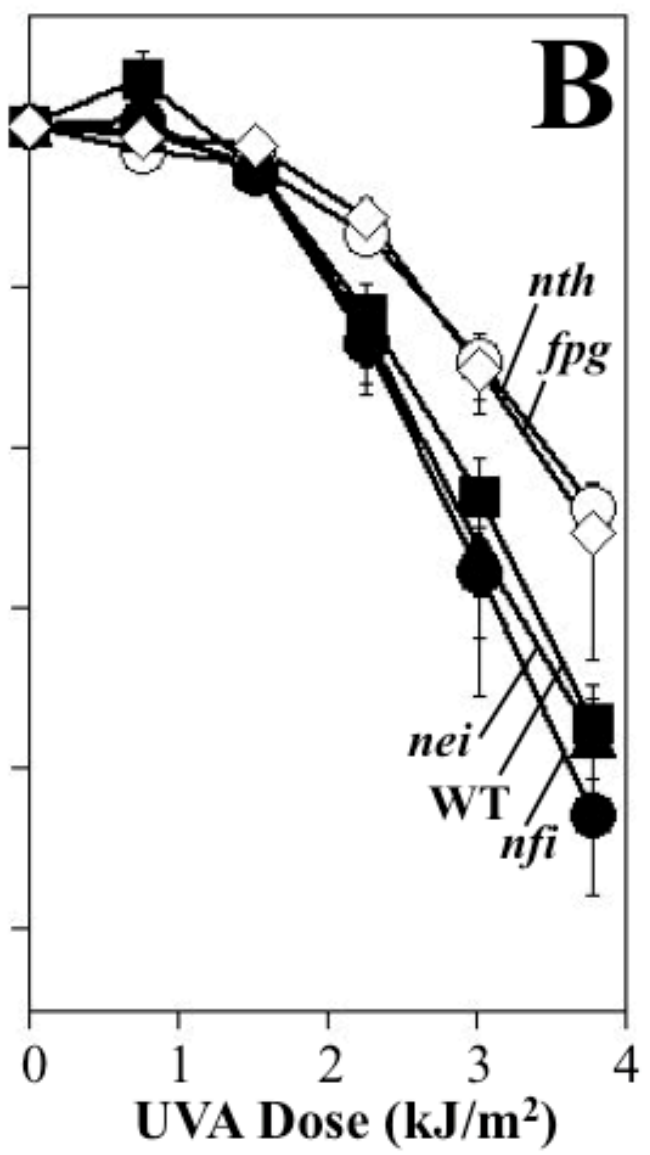

Figure 3.1. Glycosylases Nei and Fpg and endonucleases Nfi and Nth are not required for 8-methoxysproalen-induced interstrand cross-link survival in E. coli. The survival of WT (closed squares), nei-(closed triangles), fpg-(open diamonds), $n f i$-(closed circles), and $n$ th-(open circles)deficient cells following UVA irradiation in the presence of A) 40 $\mu \mathrm{g} / \mathrm{mL}$ angelicin or B) $10 \mu \mathrm{g} / \mathrm{mL}$ 8-methoxypsoralen. Angelicin produces monoadducts based on its angular structure (depicted above A) whereas 8-methoxypsoralen can produce both monoadducts and DNA interstrand cross-links due to its linear structure (depicted above B). Graphs represent an average of at least 3 experiments. Error bars represent standard error of the mean.

Following binding and incisions by DNA glycosylases, the next step in base excision repair is carried out by AP endonucleases, which are required to incise the DNA 
backbone and release the bound glycosylases from the lesion $(54,55)$. E. coli has two AP endonucleases, Exo III and Endo IV, encoded by $x$ th and $n f o$, respectively (48). Similar to that seen in fpg and $n$th mutants, deletion of $x$ th conferred a modest resistance to both angelicin and 8-methoxypsoralen-damage (Figure 3.2). By comparison, although inactivation of $n f o$ did not affect the survival in in the presence of angelicin, it conferred a modest resistance that was specific to 8-methoxypsoralen-treatement. These observations suggest that base excision repair gylcosylases and AP endonucleases modestly sensitize cells to psoralen-induced damage. With the exception of Endo IV, a similar sensitization was observed in the presence of either angelicin or 8-methoxypsoralen, suggesting that the pathway is acting upon the monoadduct product and not interstrand cross-links. In the case of Endo IV, the data could suggest that the enzyme is specific for interacting with interstrand cross-links or that it may distinguish between angelicin and 8methoxypsoralen structures, thus only recognizing the 8-methoxypsoralen monoadduct. Considering that all other enzymes appear to operate on the monoadduct, we favor the latter interpretation, but cannot exclude the possibility that Endo IV is uniquely recognizing interstrand cross-links. 

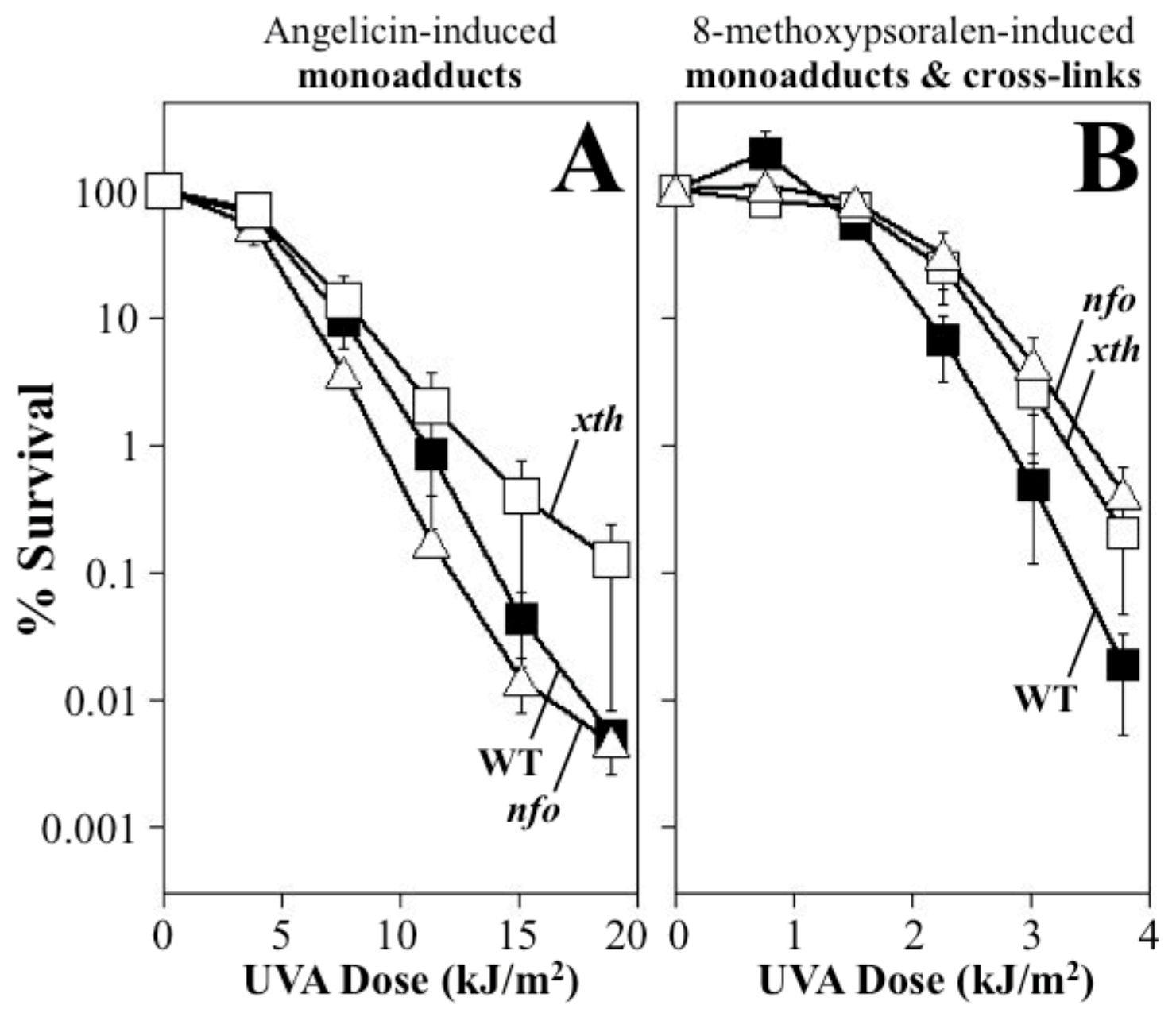

Figure 3.2. Inactivation of Endonuclease IV confers resistance to 8-methoxypsoraleninduced damage. The survival of WT (closed squares), $x t h$-(open squares), and $n f o$-(open triangles) deficient cells following UVA irradiation in the presence of A) $40 \mu \mathrm{g} / \mathrm{mL}$ angelicin or B) $10 \mu \mathrm{g} / \mathrm{mL}$ 8-methoxypsoralen. Anglicin produces monoadducts whereas 8-methoxypsoralen produces monoadducts and DNA interstrand cross-links. Graphs represent an average of at least 3 experiments. Error bars represent standard error of the mean.

To further characterize whether base excision repair's mode of action was centered on the monoadduct or interstrand cross-link, we examined how the enzyme's presence affected the rate that these lesions were formed and incised. We reasoned that if the base excision repair enzymes impede cross-link removal, then mutants lacking the glycosylases or AP endonucleases may incise these lesions are a faster rate. To examine 
the rate of cross-link incision, cultures containing plasmid pBR322 were irradiated with UVA in the presence of 8-methoxypsoralen and then allowed to recover. At various times during the two-hour recovery period aliquots of each culture were collected and total genomic and plasmid DNA was purified then restricted with HindIII to linearize the plasmid. The form of the plasmid DNA was determined by Southern analysis following alkali denaturing agarose electrophoresis. Under denaturing conditions, DNA molecules that contain DNA interstrand cross-links are prevented from separating and can be detected due to their slower migration pattern relative to linear, single-stranded DNA (56, 57). In wild type cells, over $80 \%$ of the cross-links were incised by the end of the twohour recovery period (Figure 3.3). By contrast, in $u v r A$ mutants the rate of incision was severely impaired, with the majority of cross-links remaining unincised throughout the recovery period. When we examined a mutant lacking the $f p g, n t h$, and nei glycosylases, the rate of cross-link incision was not detectably different than that seen in wild type cells. Similarly, in cultures lacking either the Exo III or Endo IV AP endonuclease, the rate of cross-link incision was similar to that seen in wild type cells. Thus, the absence of these base excision repair gene products does not alter the rate of cross-link incision. 


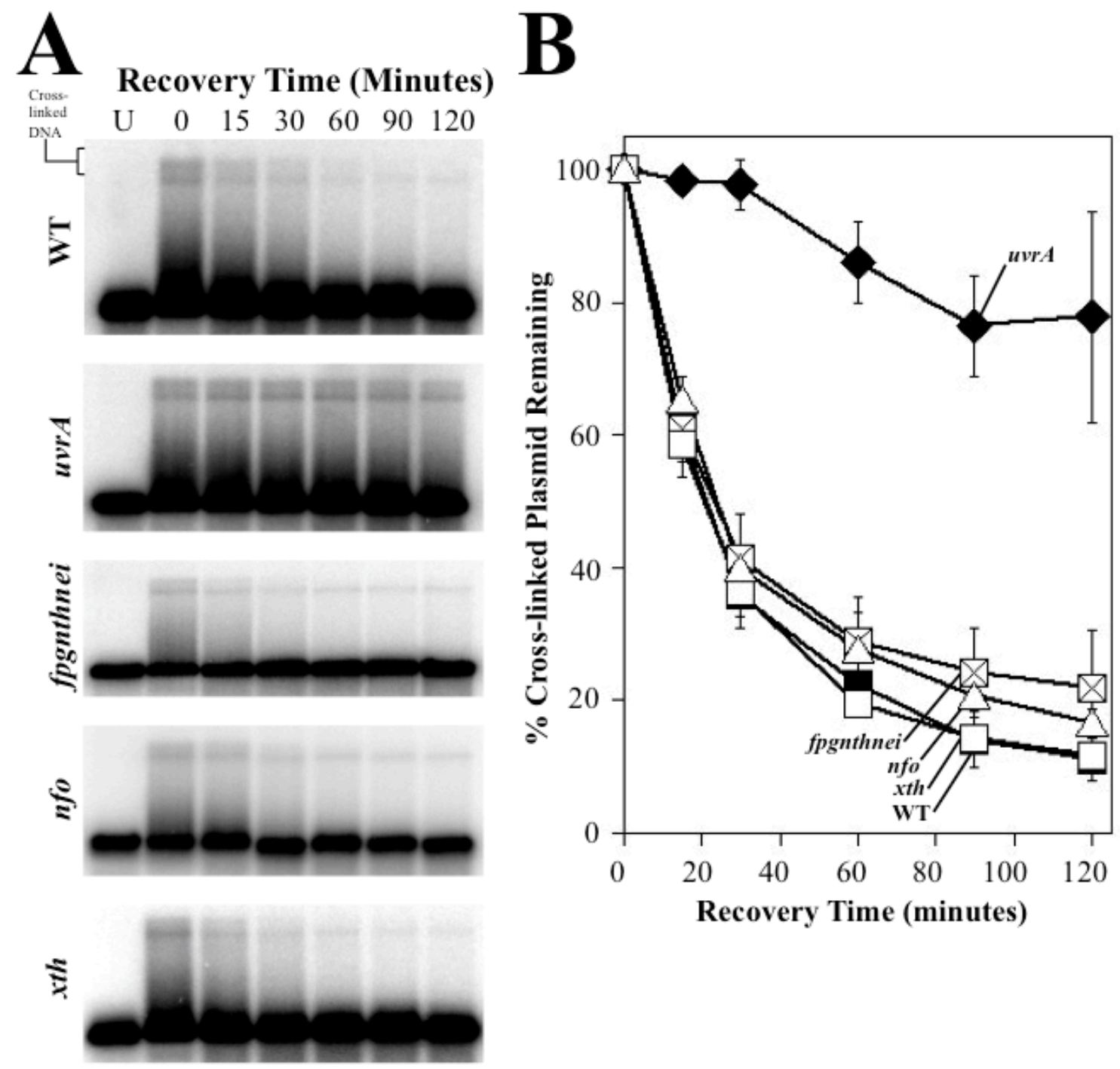

Figure 3.3. Inactivation of glycosylases or AP endonuclease activity does not alter incision rate of 8-methoxypsoralen cross-links from $E$. coli cells containing plasmid pBR322. A) Cultures containing pBR322 were UVA irradiated with $5.7 \mathrm{~kJ} / \mathrm{m}^{2}$ in the presence of $20 \mu \mathrm{g} / \mathrm{mL}$ of 8 -methoxypsoralen and then allowed to recover for 120 minutes. To examine the cross-links remaining at time points during the recovery period, total genomic and plasmid DNA was purified from cells, restricted with HindIII to linearize the plasmid, and examined by Southern analysis following alkali gel electrophoresis using ${ }^{32} \mathrm{P}$-labeled pBR322 as a probe. B) The fraction of cross-links remaining in the DNA during the recovery period is plotted for WT (filled squares), $u v r A$ (filled diamonds), fpg $n$th nei (open squares with $\mathrm{X}$ ), nfo (open triangles), and $x$ th (open squares). The initial percentage of cross-linked plasmids immediately following UVA irradiation (time 0) were WT 4.2\% $\pm 0.7 ;$ uvrA 4.4\% $\pm 0.5 ;$ fpg nth nei $3.0 \% \pm 0.1 ; n f o$ $4.5 \% \pm 0.1 ; x$ th $4.5 \% \pm 0.3$. 
In addition to the rate of cross-link incision, we also monitored and compared the rate that cross-links were formed in wild type, excision defective $u v r A$, the fpg nth nei glycosylase mutant, and AP endonuclease mutant $n f o$. To this end, cultures containing the plasmid pBR322 were UVA-irradiated in the presence of 8-methoxypsoralen for increasing amounts of time. Total DNA was purified from treated cultures at times indicated, linearized with HindIII, and examined by Southern analysis following alkali agarose gel electrophoresis. In wild type cultures, the amount of interstrand cross-links increased with time of irradiation with $\sim 10 \%$ of the plasmids containing a cross-link following $34 \mathrm{~kJ} / \mathrm{m}^{2} \mathrm{UVA}$ (Figure 3.4). By comparison, in $u v r A$ mutants an elevated level of cross-links was observed at each UVA dose relative to wild type cultures, consistent with the idea that neither the monoadducts nor cross-links can be removed or incised, respectively, in these mutants. Cultures lacking Fapy, Endo III, and Endo VIII glycosylases displayed a rate of cross-link induction that was similar to that of wild type cells.

We also noted that in the absence of the glycosylases, a unique intermediate appeared which migrated progressively faster than the single cross-link product as the UVA dose increased. At present, we are unable to identify this intermediate. However, in previous work, we've noted a similar progressively increasing mobility of the cross-link band occurring at high UVA doses, after the entire population of plasmids has been cross-linked. We attributed this increased mobility to plasmids containing multiple crosslinks, which would limit the ability of the arms to denature, resulting in a plasmid having a more linear, faster migrating shape. Although the mobility is similar here, it is not clear why multiple cross-links would form only on a subset of the plasmids. Further, this effect 
appears to only occur in the glycosylase mutants. Since the effect is not observed in the nfo-mutant, which is also hyperresistant to psoralen-induced damage, we think the multicross-linked species or intermediate is unlikely to be responsible for the hyperresistance of the glycosylase mutant.

A second possibility is that this accumulating band shift represents a repair intermediate. A single incision of one strand may also produce a smaller product that migrates faster. However, this observation is not consistent with the observation that the species appears to progressively migrate faster as the dose increases. Further, since this intermediate does not appear in wild type cells or in $n f o$-mutants - which are also hyperresistant — it seems unlikely that it represents a true 'repair' intermediate.

In the AP endonuclease mutant, $n f o$, the rate of cross-link formation is also similar to that of wild type cells. The lack of effect in glycosylase incision or formation is interesting considering that the mutant as resistant to psoralen- but not angelicin-induced damage. The lack in difference of activity towards cross-links supports the idea that Endo IV operates on the monoadduct form of psoralen-induced damage.

Directly monitoring the removal or induction of monoadducts in vivo is more challenging than that of cross-links. Although we were not able to determine the number of monoadducts present in each plasmid molecule, the accumulation of monoadducts does appear to modestly retard the mobility of the linear plasmid. This is most apparent in the $u v r A$-mutant, where the linear plasmid band progressively shifts up as the UVA dose increases and more monoadducts form on the DNA molecule. In wild type cells, a similar but less prominent shift of the linear DNA occurs as UVA dose increases, likely reflecting the ability to remove the lesions during the period of irradiation, which occurs 
over a 90-minute period (Figure 3.4A). By comparison, however, no noticeable shift occurred in either the $n f o$ - or fpg nth nei-deficient cultures, suggesting that fewer monoadducts were forming in these mutants at each dose of UVA. In Figure 3.4C we quantified the decrease of the initial linear band area per UVA dose over total DNA per lane.

fpg nth nei-deficient cultures appeared to accumulate total damage at a slower rate than wild type cells (Figure 3.4C). Although we are unable to quantify the number of monoadducts required to shift the linear band, a slower rate of monoadduct formation in these base excision repair mutants could explain the modest resistance observed to both angelicin and psoralen in these mutants and suggests that the presence of these enzymes may impede monoadduct removal. 


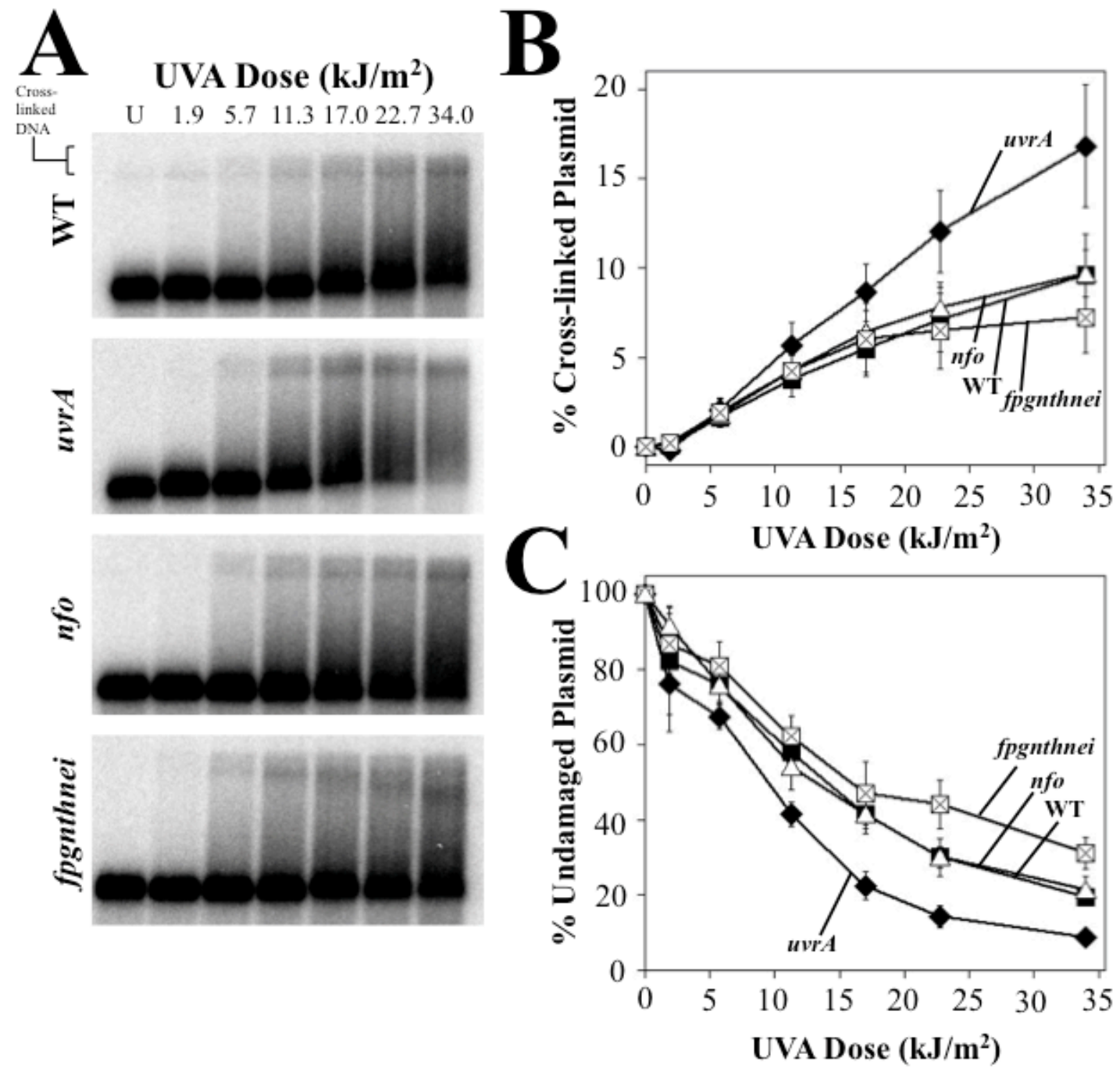

Figure 3.4. Cross-link induction in base excision repair mutants is similar to induction in wild type cells. A) Dose response of interstrand cross-links formation in vivo. Wild type, $u v r A$-, fpg nth nei-, and $n f o$-deficient cultures containing plasmid pBR322 were exposed to increasing doses of UVA light in the presence of $10 \mu \mathrm{g} / \mathrm{mL} 8$-methoxypsoralen. DNA from cultures was purified and analyzed as in Figure 3 to observe interstrand cross-link formation at each dose indicated. B) The percent of cross-linked plasmid (4.3 kB) at each dose is plotted per strain: WT (filled squares), uvrA (filled diamonds), fpg nth nei (open squares with $\mathrm{X}$ ), and $n f o$ (open diamonds). C) The percent linear DNA at ease dose is plotted per strain.

\section{Discussion}

Here we show that glycosylase mutants $f p g$ and $n t h$ and AP endonuclease mutant $x t h$ are modestly resistant in the presence of angelicin monoadducts as well as 8- 
methoxypsoralen monoadducts and cross-links compared to wild type cells. Since the mutants are about equally as resistant to either chemical plus UVA light, we infer that the sensitivity observed in presence of these gene products was due to their detrimental interaction with monoadducts, not cross-links. Alternatively, AP endonuclease mutant $n f o$ was specifically resistant to 8-methoxypsoralen cross-links and monoadducts, which could mean that either the functional protein operates specifically, albeit negatively, with cross-links or that it interacts with 8-methoxypsoralen monoadducts but not angelicin monoadducts due to difference in isomer structure. Purified Fpg and Nei have both been shown to bind and incise monoadducts as well as an unhooked three-stranded diadduct in vitro (25). However, we found that neither the glycosylases or AP endonucleases altered the rate of cross-link incision or formation in vivo. The resistance of these mutants and the lack of effect on the incision rate argue against the idea that these enzymes promote repair of cross-links in cells. These observations, coupled with the resistance seen in angelicin-treated cells, support the interpretation that base excision repair proteins might interact specifically with monoadducted DNA.

Other observations that support the idea that base excision repair proteins operate on psoralen monoadducts can be seen in the dose curve blots of wild type, $n f o-$, and $u v r A$ deficient cells where the linear band slowly migrates upward as UVA increases (Figure 4A). This is more prevalent in the $u v r A$ mutants, presumably because monoadducts are not incised in this strain and would cause denatured DNA to run slightly slower than damage-free single stranded DNA. Because this is seen in wild type cells but not in triple glycosylase mutants, we would propose that when these proteins are present they interact 
with monoadduct DNA and obstruct other repair enzymes, such as those in the nucleotide excision repair pathway, from gaining access to the lesions to effect removal.

Cross-link formation by 8-methoxypsoralen and UVA light occurs in a sequence of steps where a molecule intercalates DNA, undergoes photoactivation of the furan ring with a thymine base, and then undergoes a second photoactivation of the pyrone ring with an adjacent thymine. Monoadducts that occur on the pyrone ring are not precursors for cross-linking $(36,59)$. As previously mentioned, Couvé et al. demonstrated that Fpg and Nei glycosylases are capable of excising psoralen monoadducts (24) as well as unhooked three-stranded diadducted oligos (25), however the substrates that these studies focused on were of 8-methoxypsoralen covalently bound to DNA from the molecule's pyrone ring. If it were the case that one the base excision repair proteins examined here operate explicitly on pyrone-side adducts, then it would make sense why we did not observe a difference in cross-link formation in the glycosylase mutants. This is because this form of damage cannot be converted into a cross-link and therefore its repair would not slow down cross-link formation in either wild type or glycosylase-deficient cells. If these enzymes do operate to remove pyrone-side monoadducts in a manner that impedes another pathway from processing them more pragmatically, then this would agree with our observation that mutants survive angelicin or 8-methoxytreatment better than wild type cells.

\section{References}

1. Kohn KW (1996) Beyond DNA cross-linking: history and prospects of DNAtargeted cancer treatment-fifteenth Bruce F. Cain Memorial Award Lecture. Cancer research 56:5533-5546. 
2. Lerner AB, Dendton CR, Fitzpatrick TB (1953) Clinical and experimental studies with 8-methoxypsoralen in vitiligo. J Invest Dermatol 20(4):299-314.

3. Honig B, Morison WL, Karp D (1994) Photochemotherapy beyond psoriasis. J Am Acad Dermatol 31(5 Pt 1):775-790.

4. Bond CA, Grant K, Boh L (1981) Photochemotherapy of psoriasis with methoxsalen and longwave ultraviolet light (PUVA). American Journal of HealthSystem Pharmacy

5. Brookes P, Lawley PD (1961) The reaction of mono- and di-functional alkylating agents with nucleic acids. Biochem J 80(3):496-503.

6. Lawley PD, Brookes P (1968) Cytotoxicity of alkylating agents towards sensitive and resistant strains of Escherichia coli in relation to extent and mode of alkylation of cellular macromolecules and repair of alkylation lesions in deoxyribonucleic acids. Biochem J 109(3):433-447.

7. Chatterjee PK, Cantor CR (1978) Photochemical production of psoralen - DNA monoadducts capable of subsequent photocrosslinking. Nucleic Acids Res 5(10):3619-3633.

8. Tessman JW, Isaacs ST, Hearst JE (1985) Photochemistry of the furan-side 8methoxypsoralen-thymidine monoadduct inside the DNA helix. Conversion to diadduct and to pyrone-side monoadduct. Biochemistry 24(7):1669-1676.

9. Venturini S et al. (1980) Comparative mutagenicity of linear and angular furocoumarins in Escherichia coli strains deficient in known repair functions. Chem Biol Interact 30(2):203-207.

10. Vare D et al. (2012) DNA interstrand crosslinks induce a potent replication block followed by formation and repair of double strand breaks in intact mammalian cells. DNA Repair (Amst) 11(12):976-985.

11. Dall'Acqua F, Marciani S, Ciavatta L, Rodighiero G (1971) Formation of interstrand cross-linkings in the photoreactions between furocoumarins and DNA. $Z$ Naturforsch B 26(6):561-569.

12. Sladek FM, Munn MM, Rupp WD, Howard-Flanders P (1989) In vitro repair of psoralen-DNA cross-links by RecA, UvrABC, and the 5'-exonuclease of DNA polymerase I. J Biol Chem 264(12):6755-6765.

13. Cole RS (1973) Repair of DNA containing interstrand crosslinks in Escherichia coli: sequential excision and recombination. Proc Natl Acad Sci U S A 70(4):10641068.

14. Berardini M, Mackay W, Loechler EL (1997) Evidence for a recombinationindependent pathway for the repair of DNA interstrand cross-links based on a sitespecific study with nitrogen mustard. Biochemistry 36(12):3506-3513.

15. Bessho T (2003) Induction of DNA replication-mediated double strand breaks by psoralen DNA interstrand cross-links. J Biol Chem 278(7):5250-5254.

16. Niedernhofer LJ et al. (2004) The structure-specific endonuclease Ercc1-Xpf is required to resolve DNA interstrand cross-link-induced double-strand breaks. $\mathrm{Mol}$ Cell Biol 24(13):5776-5787.

17. De Silva IU, McHugh PJ, Clingen PH, Hartley JA (2000) Defining the roles of nucleotide excision repair and recombination in the repair of DNA interstrand cross-links in mammalian cells. Mol Cell Biol 20(21):7980-7990. 
18. Van Houten B, Gamper H, Holbrook SR, Hearst JE, Sancar A (1986) Action mechanism of $\mathrm{ABC}$ excision nuclease on a DNA substrate containing a psoralen crosslink at a defined position. Proc Natl Acad Sci U S A 83(21):8077-8081.

19. Shen DW, Pouliot LM, Hall MD, Gottesman MM (2012) Cisplatin resistance: a cellular self-defense mechanism resulting from multiple epigenetic and genetic changes. Pharmacol Rev 64(3):706-721.

20. Jacobsen C, Honecker F (2015) Cisplatin resistance in germ cell tumours: models and mechanisms. Andrology 3(1):111-121.

21. Sarin N et al. (2017) Cisplatin resistance in non-small cell lung cancer cells is associated with an abrogation of cisplatin-induced $\mathrm{G} 2 / \mathrm{M}$ cell cycle arrest. PLoS One 12(7): $\mathrm{e} 0181081$.

22. Bridges BA, von Wright A (1981) Influence of mutations at the rep gene on survival of Escherichia coli following ultraviolet light irradiation or 8methoxypsoralen photosensitization: evidence for a recA+ rep+-dependent pathway for repair of DNA crosslinks. Mutat Res 82(2):229-238.

23. Allan JM et al. (1998) Mammalian 3-methyladenine DNA glycosylase protects against the toxicity and clastogenicity of certain chemotherapeutic DNA crosslinking agents. Cancer Res 58(17):3965-3973.

24. Couvé-Privat S, Macé G, Rosselli F, Saparbaev MK (2007) Psoralen-induced DNA adducts are substrates for the base excision repair pathway in human cells. Nucleic Acids Res 35(17):5672-5682.

25. Couvé S, Macé-Aimé G, Rosselli F, Saparbaev MK (2009) The human oxidative DNA glycosylase NEIL1 excises psoralen-induced interstrand DNA cross-links in a three-stranded DNA structure. J Biol Chem 284(18):11963-11970.

26. Wang D et al. (2009) APE1 overexpression is associated with cisplatin resistance in non-small cell lung cancer and targeted inhibition of APE1 enhances the activity of cisplatin in A549 cells. Lung Cancer 66(3):298-304.

27. Kothandapani A et al. (2011) Novel role of base excision repair in mediating cisplatin cytotoxicity. J Biol Chem 286(16):14564-14574.

28. McNeill DR et al. (2013) NEIL1 responds and binds to psoralen-induced DNA interstrand crosslinks. J Biol Chem 288(18):12426-12436.

29. Semlow DR, Zhang J, Budzowska M, Drohat AC, Walter JC (2016) ReplicationDependent Unhooking of DNA Interstrand Cross-Links by the NEIL3 Glycosylase. Cell 167(2):498-511.e14.

30. Wang S et al. (2016) Characterization of a novel DNA glycosylase from S. sahachiroi involved in the reduction and repair of azinomycin B induced DNA damage. Nucleic Acids Res 44(1):187-197.

31. Mullins EA, Warren GM, Bradley NP, Eichman BF (2017) Structure of a DNA glycosylase that unhooks interstrand cross-links. Proc Natl Acad Sci US A 114(17):4400-4405.

32. Cole RS (1971) Psoralen monoadducts and interstrand cross-links in DNA. Biochimica et Biophysica Acta (BBA)-Nucleic Acids and ...

33. Tomasz M et al. (1986) Reaction of DNA with chemically or enzymatically activated mitomycin $\mathrm{C}$ : isolation and structure of the major covalent adduct. Proc Natl Acad Sci US A 83(18):6702-6706. 
34. Tomasz M et al. (1987) Isolation and Structure of a Covalent Cross-Link Adduct between Mitomycin C and DNA. Science 235(4793):1204-1208.

35. Kaye J, Smith CA, Hanawalt PC (1980) DNA repair in human cells containing photoadducts of 8-methoxypsoralen or angelicin. Cancer Res 40(3):696-702.

36. Kanne D, Straub K, Rapoport H, Hearst JE (1982) Psoralen-deoxyribonucleic acid photoreaction. Characterization of the monoaddition products from 8methoxypsoralen and 4,5'8-trimethylpsoralen. Biochemistry 21(5):861-871.

37. Cao H, Hearst JE, Corash L, Wang Y (2008) LC-MS/MS for the detection of DNA interstrand cross-links formed by 8-methoxypsoralen and UVA irradiation in human cells. Anal Chem 80(8):2932-2938.

38. Lai C et al. (2008) Quantitative analysis of DNA interstrand cross-links and monoadducts formed in human cells induced by psoralens and UVA irradiation. Anal Chem 80(22):8790-8798.

39. Liu S, Wang Y (2013) A quantitative mass spectrometry-based approach for assessing the repair of 8-methoxypsoralen-induced DNA interstrand cross-links and monoadducts in mammalian cells. Anal Chem 85(14):6732-6739.

40. Bordin F, Carlassare F, Baccichetti F, Anselmo L (1976) DNA repair and recovery in Escherichia coli after psoralen and angelicin photosensitization. Biochim Biophys Acta 447(3):249-259.

41. Ashwood-Smith MJ, Grant E (1977) Conversion of psoralen DNA monoadducts in E. coli to interstrand DNA cross links by near UV light (320-360 nm): Inability of angelicin to form cross links, in vivo. Experientia 15;33(3):384-386.

42. Perera AV, Mendenhall JB, Courcelle CT, Courcelle J (2016) Cho Endonuclease Functions during DNA Interstrand Cross-Link Repair in Escherichia coli. $J$ Bacteriol 198(22):3099-3108.

43. Courcelle J, Carswell-Crumpton C, Hanawalt PC (1997) recF and recR are required for the resumption of replication at DNA replication forks in Escherichia coli. Proc Natl Acad Sci U S A 94(8):3714-3719.

44. Mellon I, Hanawalt PC (1989) Induction of the Escherichia coli lactose operon selectively increases repair of its transcribed DNA strand. Nature 342(6245):95-98.

45. Courcelle J, Crowley DJ, Hanawalt PC (1999) Recovery of DNA replication in UVirradiated Escherichia coli requires both excision repair and recF protein function. $J$ Bacteriol 181(3):916-922.

46. Schalow BJ, Courcelle CT, Courcelle J (2011) Escherichia coli Fpg glycosylase is nonrendundant and required for the rapid global repair of oxidized purine and pyrimidine damage in vivo. J Mol Biol 410(2):183-193.

47. Guo G, Weiss B (1998) Endonuclease V (nfi) mutant of Escherichia coli K-12. J Bacteriol 180(1):46-51.

48. Cunningham RP, Saporito SM, Spitzer SG, Weiss B (1986) Endonuclease IV (nfo) mutant of Escherichia coli. J Bacteriol 168(3):1120-1127.

49. Yu D et al. (2000) An efficient recombination system for chromosome engineering in Escherichia coli. Proc Natl Acad Sci U S A 97(11):5978-5983.

50. Murphy KC, Campellone KG, Poteete AR (2000) PCR-mediated gene replacement in Escherichia coli. Gene 246(1-2):321-330.

51. Davis BD (1949) The Isolation of Biochemically Deficient Mutants of Bacteria by 
Means of Penicillin. Proc Natl Acad Sci U S A 35(1):1-10.

52. Rodighiero G, Musajo L, Dall'Acqua... F (1970) Mechanism of skin photosensitization by forucoumarins: Photoreactivity of various furocoumarins with native DNA and with ribosomal RNA. ... et Biophysica Acta (BBA ...

53. Mu D et al. (2000) DNA interstrand cross-links induce futile repair synthesis in mammalian cell extracts. Mol Cell Biol 20(7):2446-2454.

54. Doetsch PW, Cunningham RP (1990) The enzymology of apurinic/apyrimidinic endonucleases. Mutat Res 236(2-3):173-201.

55. Erzberger JP, Barsky D, Schärer OD, Colvin ME, Wilson DM (1998) Elements in abasic site recognition by the major human and Escherichia coli apurinic/apyrimidinic endonucleases. Nucleic Acids Res 26(11):2771-2778.

56. Vos JH, Hanawalt PC (1987) Processing of Psoralen Adducts in an Active Human Gene: Repair and Replication of DNA Containing Monoadducts and Interstrand Crosslinks. Cell 50:789-799.

57. Islas AL, Vos JM, Hanawalt PC (1991) Differential introduction and repair of psoralen photoadducts to DNA in specific human genes. Cancer Res 51(11):28672873.

58. Long DT, Räschle M, Joukov V, Walter JC (2011) Mechanism of RAD51dependent DNA interstrand cross-link repair. Science 333(6038):84-87.

59. Kanne D, Straub K, Hearst JE, Rapoport H (1982) Isolation and Characterization of Pyrimidine-Psoralen-Pyrimidine Photodiadducts from DNA. J Am Chem Soc 104:6754-6764. 
Chapter IV: Conclusion

DNA interstrand cross-links are a highly disruptive form of damage in cells that induce lethality if not repaired (1). The mechanisms of repair have been challenging to study but are extremely important to understand when considering the development of new cross-link-based chemotherapeutics (2)(3). Additionally, characterizing the cellular pathways involved in DNA interstrand cross-link repair could benefit future treatment of patients with Fanconi anemia (4). Early cross-link repair studies in E. coli demonstrated that these lesions were incised from DNA in repair proficient cells but not in strains with defective nucleotide excision repair enzymes (5). Experiments have since been conducted in a variety of model systems such as yeast, Drosophila, Xenopus, and mammalian cells which all have shared repair mechanisms for removing cross-links but each differ in complexity of the pathways involved (6). Mammalian model systems have suggested the involvement of numerous FANC proteins - those associated with the Fanconi anemia pathway - as well as enzymes from multiple repair pathways but delineating the overall process has proven challenging to recapitulate in vivo (7) (8). Therefore, the aim of this study was to provide in vivo evidence for cross-link repair following the initial incision steps by nucleotide excision repair by returning to experiments in $E$. coli-a simplified model organism with highly conserved repair pathways.

In order to accomplish this, E. coli cultures deficient in candidate repair genes were examined for their sensitivity to 8-methoxypsoralen+UVA-induced cross-links and survival capacity relative to wild type cells. Because 8-methoxypsoralen-UVA treatment also induces single-stranded damage, the monofunctional isomer angelicin was used to 
compare sensitivity of mutant strains to damage induced by either chemical (9). First, candidates from the nucleotide excision repair pathway were examined to determine if the $u v r D$ gene product would contribute to survival of cross-links. The observation that a $u v r D$ mutant was nearly as resistant to 8-methoxypsoralen treatment as wild type cells but nearly as sensitive to angelicin treatment as $u v r A$ mutants suggested that when present, the UvrD enzyme only contributes to the repair of monoadducts. To confirm this, the incision of cross-links from endogenous plasmids was examined via Southern blot analysis following UVA irradiation in the presence of 8-methoxypsoralen in wild type, $u v r A$-, and $u v r D$-deficient strains. Surprisingly, $u v r D$ mutants have an impaired capacity for incising cross-links, just like $u v r A$ mutants. This observation seemed to conflict with the survival results raising the question of how a $u v r D$ mutant could survive similar to wild type cells while having a diminished to almost negligible capacity for incising crosslinks from endogenous plasmid DNA.

In order to resolve this conflict, an additional Southern blot analysis was performed to examine the rate of cross-link formation and from this determine the number of cross-links capable of inducing lethality in wild type cultures. It was observed that one cross-link per $E$. coli chromosome is sufficient to inactivate wild type cell cultures. This quantity is lower than previously reported but comports with our observations that nucleotide excision repair enzymes may be necessary to incise crosslinks but that this processing event does not contribute to survival in E. coli. Additionally, we show via survival analysis that double-strand breaks are not a predominant intermediate in cross-link repair and that translesion synthesis does not contribute to survival of cross-links. Evidence for this was that $\operatorname{recN}$ mutants and polBdinBumuDC 
mutants are equally sensitive to UVA irradiation in the presence of angelicin or 8methoxypsoralen.

The final candidate pathway that was examined in this study was base excision repair. Glycosylase mutants- $f p g, n t h, n f i$, and $n e i-$ were examined as well as apurinic/apyrimidinic (AP) endonuclease mutants - $x t h$ and $n f_{o}$ - for their sensitivity to psoralen treatments. While none of these mutants exhibited any sensitivity relative to wild type cells, $f p g$, $n t h$, and $x t h$ mutants exhibited resistance to both isomers of psoralen, suggesting that when these gene products are present they sensitize cells through interactions with monoadducts, not cross-links. Additionally, cells deficient in AP endonuclease Endo IV ( $n f o$ ) exhibited resistance exclusively to UVA irradiation in the presence of 8-methoxypsoralen treatment. Southern blot analysis was performed to determine if this resistance was specific to cross-links or just the linear monoadduct structure of this isomer by examining if the rate of cross-link incisions was enhanced in the resistant mutants or if cross-links formed more slowly. In either case, mutants exhibited phenotypes that were indistinguishable from wild type cells. However, what did slightly differ in the dose curve blots was that the shift of linear, undamaged DNA was slower in triple glycosylase mutant—fpgnthnei-suggesting that the formation of monoadducts may be impeded when these gene products are absent. Additionally, a DNA intermediate was observed from this mutant that migrated just below the cross-link band and seemed to accumulate as UVA dose increased.

Although we were unable to characterize this intermediate, we infer that the structure either represents the accumulation of more cross-links or that it is an incision byproduct on a plasmid molecule that contains at least one cross-link. The latter seems 
more reasonable since these mutants are associated with a greater capacity for survival relative to wild type cells. Furthermore, it would support the argument that the glycosylases operate on monoadduct structures and impede their removal by other repair pathways such as nucleotide excision repair. In summary, although cross-links are capable of being processed in wild type cells, the observation that one cross-link is sufficient for reducing survival of cell in cultures to $37 \%$ suggests that the repair enzymes involved are not capable of restoring the integrity of the DNA following damage in $E$. coli. The results that support these conclusions are summarized in Table 4.1.

Table 4.1 Summary of in vivo results of E. coli mutants from candidate DNA interstrand cross-link repair pathways relative to wild type cells.

\begin{tabular}{|c|c|c|c|c|c|}
\hline \multirow[b]{3}{*}{$\begin{array}{l}\text { Candidate } \\
\text { repair } \\
\text { pathway }\end{array}$} & \multirow[b]{3}{*}{$\begin{array}{c}\text { Mutant } \\
\text { examined }\end{array}$} & \multicolumn{4}{|c|}{ Results relative to wild type cells } \\
\hline & & \multicolumn{2}{|c|}{ Survival analysis } & \multicolumn{2}{|c|}{ Southern blot analysis } \\
\hline & & $\begin{array}{l}\text { Angelicin } \\
\text { + UVA }\end{array}$ & $\begin{array}{c}\text { 8-methoxy- } \\
\text { psoralen } \\
\text { + UVA }\end{array}$ & $\begin{array}{c}\text { Cross-link } \\
\text { incision } \\
\text { rate }\end{array}$ & $\begin{array}{c}\text { Cross-link } \\
\text { induction } \\
\text { rate }\end{array}$ \\
\hline \multirow{2}{*}{$\begin{array}{c}\text { Nucleotide } \\
\text { Excision Repair }\end{array}$} & $u v r A-$ & sensitive & sensitive & impaired & enhanced \\
\hline & $u v r D-$ & sensitive & equal to WT & impaired & - \\
\hline $\begin{array}{l}\text { Translesion } \\
\text { Synthesis }\end{array}$ & $\begin{array}{c}\text { polB- } \\
\operatorname{din} B- \\
\text { umuDC- }\end{array}$ & $\begin{array}{c}\text { mildly } \\
\text { sensitive }\end{array}$ & $\begin{array}{c}\text { mildly } \\
\text { sensitive }\end{array}$ & - & - \\
\hline \multirow{2}{*}{$\begin{array}{l}\text { Double-strand } \\
\text { Break Repair }\end{array}$} & $\operatorname{rec} A-$ & sensitive & sensitive & - & - \\
\hline & $\operatorname{rec} N-$ & $\begin{array}{l}\text { mildly } \\
\text { sensitive }\end{array}$ & $\begin{array}{c}\text { mildly } \\
\text { sensitive }\end{array}$ & - & - \\
\hline \multirow{6}{*}{$\begin{array}{c}\text { Base Excision } \\
\text { Repair }\end{array}$} & fpg- & resistant & resistant & & \\
\hline & nth- & resistant & resistant & equal to & equal to \\
\hline & $n e i-$ & equal to WT & equal to WT & WT* & $\mathrm{WT}^{*}$ \\
\hline & $n f i-$ & equal to WT & equal to WT & - & - \\
\hline & $x t h-$ & resistant & resistant & equal to WT & - \\
\hline & nfo- & equal to WT & resistant & equal to WT & equal to WT \\
\hline
\end{tabular}

* triple mutant of $f p g, n t h, \&$ nei was examined

- similar, with the exception of an unusal DNA intermediate

How these findings may relate to more complex organisms such as mammals has not been addressed directly in the present study but is not unimaginable since the repair 
pathways examined here are highly conserved across taxa. In humans, chromosomal abnormalities as observed by chromosomal breakage tests in Fanconi anemia blood samples indicate a clear difference between cross-link processing in these cells versus blood samples from non-afflicted persons (10). This does not contradict our inferences of minimal repair capacity in wild type cells but simply suggests that lack of repair capacity in Fanconi cells is far more destructive to replicated chromosomal structures than when cross-linking are processed, especially during replication. Furthermore, since the E. coli genome is $\sim 700$ times smaller than the human genome and is comprised mostly of geneencoding DNA it seems reasonable that human cells would have a higher capacity for damage from cross-links.

In summary, cross-links are highly lethal in E. coli and processing events appear to be non-productive in the traditional sense of eliciting a faithful repair mechanism.

\section{References}

1. Lawley PD, Brookes P (1968) Cytotoxicity of alkylating agents towards sensitive and resistant strains of Escherichia coli in relation to extent and mode of alkylation of cellular macromolecules and repair of alkylation lesions in deoxyribonucleic acids. Biochem J 109(3):433-447.

2. Kohn KW (1996) Beyond DNA cross-linking: history and prospects of DNAtargeted cancer treatment-fifteenth Bruce F. Cain Memorial Award Lecture. Cancer research 56:5533-5546.

3. McHugh PJ, Spanswick VJ, Hartley JA (2001) Repair of DNA interstrand crosslinks: molecular mechanisms and clinical relevance. Lancet Oncol 2(8):483490.

4. Bhattacharjee S, Nandi S (2017) DNA damage response and cancer therapeutics through the lens of the Fanconi Anemia DNA repair pathway. Cell Commun Signal 15(1):41.

5. Kohn KW, Steigbigel NH, Spears CL (1965) Cross-linking and repair of DNA in sensitive and resistant strains of E. coli treated with nitrogen mustard. Proc Natl Acad Sci U S A 53(5):1154-1161.

6. McVey M (2010) Strategies for DNA interstrand crosslink repair: insights from 
worms, flies, frogs, and slime molds. Environ Mol Mutagen 51(6):646-658.

7. Gueiderikh A, Rosselli F, Neto JBC (2017) A never-ending story: the steadily growing family of the FA and FA-like genes. Genet Mol Biol 40(2):398-407.

8. Cheung RS, Taniguchi T (2017) Recent insights into the molecular basis of Fanconi anemia: genes, modifiers, and drivers. Int J Hematol 106(3):335-344.

9. Bordin F, Carlassare F, Baccichetti F, Anselmo L (1976) DNA repair and recovery in Escherichia coli after psoralen and angelicin photosensitization. Biochim Biophys Acta 447(3):249-259.

10. Auerbach AD (1988) A test for Fanconi's anemia. Blood 72(1):366-367. 